\title{
ANALISIS KETIMPANGAN ANTARWILAYAH DAN PERGESERAN STRUKTUR EKONOMI DI KALIMANTAN
}

\section{ANAL YSIS OF ACROSS REGION INEQUALITY AND ECONOMIC STRUCTURE SHIFT IN KALIMANTAN}

\author{
Maria Christina Yuli Pratiwi \\ Bappelitbangda Kabupaten Kotawaringin Tmur. Jl. Jenderal Sudirman Km. 5,5, Sampit, Indonesia
}

How to cite: Pratiwi, Maria Christina Y.P. (2021). Analisis Ketimpangan Antarwilayah dan Pergeseran Struktur Ekonomi di Kalimantan. Jurnal Borneo Administrator, 17 (1), 131-154.

https://doi.org/10.24258/jba.v17i1.779

\begin{abstract}
Article History
Received:

25 Juni 2020

Accepted:

15 April 2021

Keywords:

Inequality

Economic Shift

Williamson Index

Shift Share

Kuznets Hypothesis

ABSTRACT

Inequality is a common problem in development, including in Indonesia. The development of Kalimantan is inseparable from the problem of inequality. This study aimed to analyze the uneven development across districts and economic structure shift of 56 districts, also to prove the capability of Kuznets Hypothesis in Kalimantan during 2012-2019. This study used secondary data which was processed by Williamson Index, Entropy Theil Index, Pearson Correlation, and Shift Share analysis. The result of study showed that: (1) regional inequality in Kalimantan is high but shows decreasing trend for the period of observation; (2) inequality between regions in Kalimantan is more caused by inequality between provinces. Province of East Kalimantan provides the largest contribution towards the inequality between and within provinces; (3) There is a strong relationship between the variable of per capita GRDP and the inequality index. Meanwhile, the relationship between the economic growth variable and the inequality index is less strong; (4) Kuznets hypothesis is not applicable in Kalimantan; (5) and the economic structure of Kalimantan has shifted from the agricultural sector to the industrial sector.
\end{abstract}

Kata kunci:

Ketimpangan

Pergeseran Ekonomi

Indeks Williamson

Shift Share

Hipotesis Kuznets

\begin{abstract}
ABSTRAK
Ketimpangan merupakan permasalahan umum dalam pembangunan, tidak terkecuali di Indonesia. Pembangunan wilayah Kalimantan juga tidak terlepas dari masalah ketimpangan. Penelitian ini bertujuan untuk menganalisis ketidakmerataan pembangunan antarwilayah dan pergeseran struktur ekonomi di 56 kabupaten/kota, serta membuktikan Hipotesis Kuznet berlaku atau tidak di Kalimantan selama periode 2012--2019. Studi ini menggunakan data sekunder yang diolah dengan analisis Indeks Williamson, Indeks Entropi Theil, Korelasi Pearson, dan Shift Share. Hasil penelitian menunjukkan bahwa: (1) ketimpangan antarwilayah di Kalimantan tergolong tinggi dengan tren yang cenderung menurun; (2) ketimpangan antarwilayah di Kalimantan lebih diakibatkan oleh
\end{abstract}

\footnotetext{
* Corresponding Author

Email : mcy.pratiwi@yahoo.co.id
} 
ketimpangan antar provinsi. Provinsi Kalimantan Timur memberi sumbangan terbesar terhadap ketimpangan antar dan dalam provinsi; (3) Terdapat hubungan yang kuat antara variabel PDRB per kapita dan indeks ketimpangan. Sedangkan hubungan antara variabel pertumbuhan ekonomi dengan indeks ketimpangan kurang kuat; (4) Hipotesis Kuznets tidak berlaku di Kalimantan; dan (5) struktur ekonomi Kalimantan mengalami pergeseran dari sektor pertanian ke sektor industri.

\section{PENDAHULUAN}

Pembangunan ekonomi memiliki pengertian yang sangat luas. Pembangunan adalah suatu perubahan mendasar ke arah kondisi yang lebih baik melalui berbagai upaya yang terencana dengan tujuan untuk meningkatkan kesejahteraan dan kualitas hidup masyarakat. Secara filosofi, proses pembangunan diartikan sebagai upaya sistematis dan berkesinambungan untuk menciptakan keadaan yang dapat menyediakan berbagai alternatif yang sah bagi pencapaian aspirasi setiap warga yang paling humanistis (Raafi'i et al., 2018:245). Todaro dan Smith (2006:62) mendefinisikan pembangunan ekonomi sebagai suatu proses yang bersifat multidimensional, melibatkan perubahan-perubahan besar baik terhadap perubahan struktur ekonomi dan sosial, mengurangi kemiskinan, ketimpangan, maupun pengangguran. Sedangkan Askar (2019:54) berpendapat bahwa pembangunan sebagai transformasi ekonomi, sosial dan budaya merupakan proses perubahan yang direncanakan untuk memperbaiki berbagai aspek kehidupan masyarakat. Menurut Tikson (2005:132), transformasi dalam struktur ekonomi terlihat melalui peningkatan atau pertumbuhan produksi yang cepat pada sektor industri dan jasa. Transformasi sosial dan budaya dapat dilihat melalui pendistribusian kemakmuran melalui pemerataan memperoleh akses terhadap sumberdaya sosial-ekonomi dan bangkitnya semangat kebangsaan dan nasionalisme serta perubahan nilai dan norma yang dianut masyarakat. Dengan demikian, proses pembangunan terjadi pada semua aspek kehidupan masyarakat, ekonomi, sosial, budaya, dan politik, yang berlangsung pada level makro (nasional) dan mikro (community/group) (Anggara, S., \& Sumantri, 2016:14).

Keberhasilan pembangunan suatu wilayah dapat terlihat dari tercapainya pertumbuhan ekonomi yang tinggi dan pemerataan pendapatan. Kedua aspek tersebut harus dapat dicapai secara bersamaan dalam proses pembangunan ekonomi (Santosa, 2015:116). Jika pertumbuhan ekonomi tidak diimbangi dengan pemerataan maka akan berdampak pada perbedaan tingkat kesejahteraan antarwilayah, yang pada akhirnya akan menyebabkan ketimpangan regional (Cita, 2016:35). Selain itu, pembagian output yang tidak merata dan hanya dinikmati oleh sebagian masyarakat dapat memicu timbulnya ketimpangan antarmasyarakat/golongan (Maulana, 2019:2). Sementara itu, menurut Ibrahim (2017:6306), pertumbuhan ekonomi yang berkualitas perlu diperkuat dengan pilihan kebijakan ekonomi yang memberikan pemihakan dan kesempatan serta akses luas kepada masyarakat. Namun, beberapa kebijakan yang dilakukan oleh pemerintah dalam meningkatkan pertumbuhan ekonomi sering kali tidak diimbangi azas keadilan dan pemerataan. Kondisi tersebut menimbulkan berbagai permasalahan dalam pembangunan, seperti kemiskinan, kesenjangan sosial-ekonomi, dan ketimpangan. Beberapa Negara terjebak pada masalah ketimpangan dan kemiskinan yang cukup parah. Amerika Serikat merupakan salah satu Negara yang pernah mengalami ketimpangan pendapatan pascapenerapan kebijakan pemerintah berupa reformasi kebijakan pajak sebesar 1 persen pada Tahun 1986 yang menyebabkan koefisien Gini Rasio meningkat 1,3 persen (Bargain et al., 2015:1067). Kondisi ketimpangan di Amerika Serikat semakin diperkuat dengan munculnya gerakan sosial Occupy Wall Street (OWS) atau Tahrir Square pada Tahun 2011 sebagai simbol protes kepada sistem kapitalis pasar global yang memicu tumbuhnya pendapatan hanya untuk segelintir penduduk (du Toit, 2015:2). Sementara itu, kebijakan moneter ekspansif yang diterapkan oleh Bank Jepang pada Tahun 2016 berupa 
kebijakan suku bunga nol dan negatif (QQE) berkontribusi besar pada melebarnya kesenjangan pendapatan antar kelompok masyarakat yang berakibat pada meningkatnya ketimpangan di Jepang (Hesary et al., 2020:2616).

Pertumbuhan ekonomi berkaitan erat dengan ketimpangan. Fenomena hubungan kedua variabel tersebut pertama kali diperkenalkan oleh Simon Kuznet pada Tahun 1955. Menurut Kuznet (1973:247), pertumbuhan ekonomi adalah kenaikan jangka panjang dari kemampuan suatu negara dalam menyediakan barang-barang ekonomi kepada penduduknya. Kuznets menyatakan bahwa pada awal proses pembangunan suatu negara, disribusi pendapatan cenderung memburuk dan ketimpangan meningkat. Proses ini akan terjadi sampai ketimpangan mencapai titik puncak dan secara berangsur-angsur ketimpangan akan menurun seiring dengan meningkatnya pendapatan perkapita. Pernyataan tersebut dikenal dengan Hipotesis Kuznets, hipotesis yang menjelaskan hubungan antara ketimpangan pendapatan dan pertumbuhan ekonomi dalam bentuk kurva $U$ terbalik. Pada tahap awal pembangunan, pertumbuhan ekonomi terpusat pada sektor modern dan terkonsentrasi di wilayah-wilayah yang sudah maju. Dengan kata lain, pertumbuhan di daerah akan lebih cepat dibandingkan dengan wilayah yang sedang berkembang. Temuan empiris yang didasarkan pada Hipotesis Kuznets adalah ketimpangan pendapatan meningkat setelah terjadi proses industrialisasi dan selanjutnya menurun ketika proses pembangunan meningkat (Nasr et al., 2018:841).

Beberapa wilayah di Indonesia mengalami pertumbuhan yang berbeda-beda, ada yang bertumbuh cepat dan ada juga wilayah yang mengalami pertumbuhan lambat (Andiny et al., 2019:47). Perbedaan tingkat pembangunan tersebut menimbulkan perbedaan tingkat kesejahteraan antarwilayah yang pada akhirnya dapat menyebabkan ketimpangan antarwilayah. Menurut Sjafrizal (2008:17), ketimpangan antarwilayah disebabkan oleh perbedaan kandungan sumber daya alam dan kondisi demografi tiap-tiap wilayah, sehingga kemampuan setiap wilayah dalam mendorong proses pembangunan juga berbeda. Perbedaan kekayaan antarwilayah menimbulkan adanya wilayah maju (developed region) dan wilayah terbelakang (underdeveloped region). Selain perbedaan potensi dan demografi wilayah, ketimpangan antarwilayah juga disebabkan karena adanya perbedaan distribusi pendapatan antar wilayah serta distribusi pengeluaran pemerintah pusat dan daerah. Ketimpangan antarwilayah di Indonesia terjadi karena pemerintah pusat menguasai dan mengendalikan hampir sebagian besar pendapatan daerah yang ditetapkan sebagai penerimaan negara. Struktur perekonomian Indonesia secara spasial masih terkonsentrasi di Kawasan Barat Indonesia (KBI). Kontribusi PDRB KBI terhadap PDB nasional sangat dominan dan tidak pernah berkurang dari 80 persen. Sedangkan Kawasan Timur Indonesia (KTI), sebagai kawasan pinggiran hanya menyumbang sekitar 17-19 persen.

Ketimpangan antarwilayah di Indonesia sangat penting untuk diteliti karena kegiatan perekonomian nasional cenderung terkonsentrasi ke KBI selama lebih dari lima dasawarsa terakhir. Pola unbalanced development di Indonesia terus terjadi sebagaimana tercermin dari kuatnya KBI sebagai pusat gravitasi pembangunan dan menyisakan KTI sebagai kawasan pinggiran. Pulau Kalimantan adalah salah satu kawasan KTI paling luas kedua setelah Papua dan penghasil devisa negara terbesar di Indonesia, tetapi pembangunannya jauh di bawah Pulau Jawa dan Sumatera. Memiliki sumber daya alam yang berlimpah, Kalimantan hanya mampu menyumbang rata-rata 8,52 persen terhadap perekonomian Indonesia. Hasil pembangunan di Kalimantan belum mampu meningkatkan kesejahteraan masyarakatnya sebagaimana terlihat dari masih banyaknya jumlah keluarga miskin, pengangguran, dan ketimpangan antarwilayah yang meningkat (BPS, 2019). Selain itu, perbedaan pendapatan per kapita antarwilayah yang cukup tinggi semakin menunjukkan bahwa distribusi pendapatan di 56 kabupaten/kota di Kalimantan belum merata dan mengindikasikan terjadinya ketimpangan antarwilayah.

Berdasarkan penjelasan di atas, diduga terjadi ketimpangan yang cukup tinggi di Kalimantan. Selain diduga terjadi ketimpangan antarwilayah, perekonomian Kalimantan 
mengalami pergeseran struktur. Selama periode 2012-2019, perekonomian Kalimantan ditopang oleh sektor pertambangan dan penggalian, industri pengolahan, serta pertanian, kehutanan, dan perikanan. Namun, sejak tiga tahun terakhir, sektor pertambangan dan penggalian serta sektor industri pengolahan mengalami penurunan peranan. Sebaliknya, peranan sektor pertanian, kehutanan, dan perikanan berfluktuasi dengan kecenderungan meningkat. Kondisi tersebut mengindikasikan bahwa perekonomian Kalimantan sedang mengalami pergeseran. Pergeseran tersebut disebabkan oleh saat ini peranan subsektor pertambangan minyak, gas dan panas bumi serta pertambangan batubara dan lignit terhadap nilai tambah sektor pertambangan dan penggalian mengalami penurunan yang diakibatkan oleh turunnya harga ekspor komoditas dan tekanan harga minyak yang cukup tinggi.

Studi mengenai ketimpangan antarwilayah dan pergeseran sektor ekonomi di 56 kabupaten/kota di Kalimantan masih sangat jarang dilakukan. Studi ini berbeda dengan studi lainnya karena penelitian tentang ketimpangan wilayah di Kalimantan yang pernah dilakukan sebelumnya hanya terbatas pada ketimpangan wilayah per provinsi dan belum ada penelitian yang membahas tentang ketimpangan antar dan dalam provinsi. Oleh karena itu, studi ini menjadi menarik dan penting untuk dilakukan. Adapun studi ini bertujuan untuk: (1) mengetahui trend ketimpangan antarwilayah di Kalimantan; (2) mengetahui ketimpangan antar dan dalam provinsi di Kalimantan; (3) mengetahui hubungan antara pertumbuhan ekonomi dan PDRB per kapita dan ketimpangan antarwilayah; (4) mengetahui Hipotesis Kuznets berlaku atau tidak di Kalimantan; dan (5) menganalisis pergeseran struktur ekonomi di Kalimantan.

\section{KERANGKA TEORI}

\section{Pengertian Ketimpangan}

Ketimpangan merupakan permasalahan umum yang terjadi pada suatu wilayah tertentu akibat tidak adanya pemerataan dalam pembangunan ekonomi. Ketimpangan dapat terjadi pada golongan keluarga atau masyarakat, antarsektor, dan antarwilayah dalam waktu tertentu. Menurut Chaniago (2011), ketimpangan adalah buah dari pembangunan yang hanya berfokus pada aspek ekonomi dan melupakan aspek sosial. Sementara Andrei \& Craciun (2015: 178) berpendapat bahwa ketimpangan adalah adanya perbedaan antara miskin dan kaya dalam distribusi pendapatan, distribusi kekayaan, pendidikan, pekerjaan, kepuasan hidup dan kebahagiaan dalam suatu negara, antar negara dan wilayah.

Menurut Kristiyanti (2007) dalam Nangarumba (2015:12), ketimpangan disebabkan oleh tiga faktor, yaitu faktor alami, sosial, dan kebijakan. Faktor alami meliputi kondisi sumber daya alam, jarak pelabuhan dengan pusat aktivitas ekonomi, lokasi geografis, dan wilayah potensial. Faktor sosial budaya berupa nilai tradisi, mobilitas ekonomi, inovasi, dan wirausaha. Sedangkan faktor yang terakhir, yaitu faktor kebijakan adalah sejumlah kebijakan yang mendukung secara langsung atau tidak langsung terjadinya ketimpangan. Kebijakan-kebijakan yang diambil pemerintah saat ini belum menunjukkan keberpihakan sepenuhnya kepada masyarakat sehingga belum seluruhnya masyarakat Indonesia dapat memperoleh manfaat proses pembangunan. Kondisi tersebut akan semakin memperlebar kemiskinan dan kesenjangan sosial-ekonomi serta mempersulit upaya untuk menekan angka ketimpangan yang ada.

Ketimpangan pendapatan menggambarkan distribusi pendapatan masyarakat di suatu wilayah pada waktu tertentu. Menurut Nangarumba (2015: 12), ketimpangan pendapatan diartikan sebagai sebuah fenomena adanya selisih atau gap antara masyarakat ekonomi ke atas dan masyarakat ekonomi ke bawah. Sementara itu, Hasanah (2017:32) berpendapat bahwa ketimpangan pendapatan menunjukkan perbedaan antara desil terkaya dan termiskin di masyarakat yang dipengaruhi oleh struktural ekonomi dan kondisi sosial di masyarakat. Sedangkan Aiyar \& Ebeke (2020:1) memiliki pendapat yang tidak jauh berbeda, yaitu 
ketimpangan pendapatan terjadi karena adanya perbedaan stratifikasi sosial dalam masyarakat. Ketimpangan pendapatan dapat disebabkan oleh beberapa hal, seperti: (1) demografi (Karahan \& Ozkan, 2013: 475); (2) globalisasi (Feenstra \& Hanson, 2008:178; Furceri et al., 2018:169), (3) struktur pasar tenaga kerja (Jaumotte \& Buitron, 2015:4), dan (4) kebijakan keuntungan pajak dan tunai (Bourguignon, 2018:16).

\section{Teori Pertumbuhan}

Pertumbuhan ekonomi merupakan salah satu indikator untuk melihat kinerja perekonomian suatu wilayah. Pertumbuhan ekonomi adalah proses perubahan perekonomian suatu negara secara berkesinambungan menuju kondisi yang lebih baik selama periode tertentu. Kuznets mendefinisikan pertumbuhan ekonomi sebagai kenaikan jangka panjang dari kemampuan suatu negara untuk menyediakan berbagai jenis barang dan jasa kepada penduduk. Sedangkan Sukirno (2013) berpendapat bahwa pertumbuhan ekonomi adalah perkembangan ekonomi yang berlaku dari waktu ke waktu dan menyebabkan pendapatan nasional riil semakin berkembang. Boediono (1999:12) memiliki pendapat berbeda, yaitu pertumbuhan ekonomi merupakan tingkatan pertambahan dari pendapatan nasional. Berdasarkan pengertianpengertian tersebut disimpulkan bahwa pertumbuhan ekonomi secara sederhana dapat diartikan sebagai pertambahan output atau pendapatan nasional agregat dalam kurun waktu tertentu. Perekonomian suatu Negara dikatakan mengalami pertumbuhan jika balas jasa riil terhadap penggunaan faktor-faktor produksi pada tahun tertentu lebih besar daripada tahun sebelumnya.

\section{Ketimpangan Wilayah}

Ketimpangan pembangunan merupakan aspek umum yang terjadi dalam kegiatan ekonomi suatu daerah. Ketimpangan antar wilayah timbul karena adanya perbedaan sumber daya dan faktor produksi. Daerah yang memiliki sumber daya dan faktor produksi, terutama barang modal akan memperoleh pendapatan yang lebih banyak. Teori Myrdal (1957) menjelaskan bahwa ketimpangan wilayah adalah kuatnya dampak balik dan lemahnya dampak sebar di negara terbelakang. Dampak balik (backwash effect) cenderung membesar dan dampak sebar (spread effect) semakin mengecil. Semakin kumulatif kecenderungan ini akan semakin memperburuk ketimpangan internasional dan menyebabkan ketimpangan di negara-negara terbelakang (Knox \& Myrdal, 1960:282).

Mubyarto (1995) membedakan ketimpangan menjadi tiga, yaitu: (1) ketimpangan antarsektor, yaitu antara sektor industri dengan sektor pertanian; (2) ketimpangan antardaerah, terjadi akibat perbedaan sumber daya yang dimiliki; dan (3) ketimpangan antargolongan ekonomi. Ketimpangan antarwilayah yang disebabkan oleh perbedaan kandungan sumber daya alam dan kondisi demografi tiap-tiap wilayah membuat kemampuan setiap wilayah dalam mendorong proses pembangunan juga berbeda. Kondisi tersebut menimbulkan adanya wilayah maju (developed region) dan wilayah terbelakang (underdeveloped region). Sementara itu, menurut Todaro \& Smith (2006), ketimpangan wilayah yang ekstrim harus mendapatkan perhatian karena dapat menyebabkan inefisiensi ekonomi, alokasi aset yang tidak efisien dan menambah jumlah kemiskinan, melemahkan stabilitas sosial dan solidaritas, serta memperkuat kekuatan politis golongan kaya sehingga menimbulkan ketidakadilan bagi masyarakat. Sedangkan Armstrong \& Taylor (1993) berpendapat bahwa ketimpangan wilayah yang substansial pada standar hidup dapat menyebabkan timbulnya ketidakpuasan pada masyarakat, tingginya tingkat pengangguran, dan terjadinya biaya-biaya ekonomi pada daerah yang berkembang.

\section{Hipotesis Kuznets}

Selama proses awal pembangunan terjadi dilema antara pencapaian pertumbuhan ekonomi yang tinggi dan pemerataan distribusi pendapatan. Kuznets (1955) mengemukakan bahwa pada 
tahap awal pertumbuhan, distribusi pendapatan akan cenderung memburuk dan ketimpangan semakin meningkat. Setelah melewati fase tersebut, distribusi pendapatan akan membaik dan ketimpangan menurun. Kuznets juga menyatakan bahwa ketika terjadi industrialisasi, tingkat ketimpangan meningkat dan terjadi migrasi dari sektor pertanian ke sektor nonpertanian. Kebenaran Hipotesis Neo-Klasik yang dikemukakan oleh Kuznets diuji kebenarannya oleh Williamson melalui studi tentang ketimpangan antarwilayah pada negara maju dan sedang berkembang dengan menggunakan data time series dan cross section. Hasil penelitian Williamson menunjukkan bahwa selama tahap awal pembangunan, ketimpangan wilayah semakin meningkat dan pembangunan terkonsentrasi di daerah-daerah tertentu. Keadaan tersebut disebabkan oleh migrasi tenaga kerja, migrasi kapita, dan pembangunan sarana publik pada daerah potensial. Menurut Williamson, Hipotesis Neo-Klasik yang diformulasikan oleh Kuznets secara teoritis ternyata terbukti benar secara empirik. Artinya, proses pembangunan suatu negara tidak otomatis dapat menurunkan ketimpangan pembangunan antarwilayah, tetapi pada tahap permulaan justru terjadi hal yang sebaliknya. Pembangunan yang menghasilkan pertumbuhan tinggi belum sepenuhnya dinikmati secara merata oleh seluruh masyarakat atau dengan kata lain belum sepenuhnya permasalahan ketimpangan antardaerah dapat teratasi.

Ketimpangan dan pertumbuhan ekonomi memiliki keterkaitan yang sangat erat. Konsistensi mengenai hubungan negatif antara ketimpangan dan pertumbuhan ekonomi diungkapkan oleh Alesina \& Rodrik (1994:485) dan Persson \& Tabellini (1994:617) yang menyatakan bahwa ketimpangan yang tinggi akan menurunkan pertumbuhan. Mayoritas rakyat miskin akan cenderung memilih kebijakan yang bersifat redistribusi daripada kebijakan yang meningkatkan pertumbuhan. Namun, teori lain muncul menyanggah pandangan tersebut sebagaimana diungkapkan oleh Paul \& Verdier (1996:719). Keduanya mengembangkan suatu model yang memprediksi bahwa dalam masyarakat yang tidak setara akan memilih kebijakan yang cenderung meningkatkan pajak untuk membiayai program-program publik seperti pendidikan yang akan meningkatkan pertumbuhan ekonomi. Sementara Li \& Zou (1998:332) berpendapat bahwa masyarakat yang lebih setara dapat menyebabkan pajak pendapatan menjadi tinggi dan pertumbuhan ekonomi menjadi rendah.

Pertumbuhan ekonomi yang diikuti oleh pembangunan ekonomi secara berkelanjutan akan mengakibatkan perubahan struktur ekonomi atau disebut juga sebagai perubahan struktural, yaitu perubahan dari sektor pertanian ke sektor industri atau jasa. Weiss (1998) menyatakan bahwa pembangunan ekonomi dalam jangka panjang akan membawa suatu perubahan mendasar dalam struktur ekonomi. Perubahan tersebut menimbulkan struktur ekonomi bergeser dari ekonomi tradisional dengan pertanian sebagai sektor utama beralih ke ekonomi modern yang didominasi oleh sektor-sektor nonprimer. Sementara Djojohadikusumo (1994) mengungkapkan bahwa perubahan struktur ekonomi berkaitan dengan perubahan-perubahan pada struktur produksi, kesempatan kerja, ketimpangan antarsektoral, antarwilayah, dan antardistribusi pendapatan. Perubahan tersebut akan mendorong kenaikan pendapatan sehingga mengakibatkan terjadinya pergeseran sektor primer ke sektor sekunder dan tersier.

Pergeseran struktur ekonomi pertama kali diperkenalkan oleh Fisher pada Tahun 1935 yang mengenalkan konsep kegiatan primer, sekunder dan tertier. Pendapat Fisher didukung oleh Lewis dengan teori model dua sektor atau Lewis two-sector model. Lewis menyatakan bahwa pada Negara berkembang terjadi transformasi struktur perekonomian dari pola perekonomian pertanian subsisten tradisional ke perekonomian yang lebih modern, yaitu sektor industri manufaktur dan sektor jasa. Teori Lewis diakui sebagai teori umum yang membahas proses pembangunan pada negara-negara dunia ketiga yang mengalami kelebihan penawaran tenaga kerja sebagaimana diungkapkan oleh Todaro \& Smith (2003). Salah satu penyebab terjadinya perubahan struktur ekonomi adalah sifat manusia dalam kegiatan konsumsi. Menurut Hukum Engels, semakin tinggi pendapatan masyarakat maka semakin sedikit proporsi pendapatan yang digunakan untuk membeli bahan pertanian, 
sebaliknya proporsi pendapatan untuk membeli barang-barang produksi industri menjadi bertambah besar. Hal ini membuat peranan sektor industri menjadi semakin besar dibanding sektor pertanian.

Penelitian tentang ketimpangan antarwilayah dan pergeseran struktur ekonomi telah banyak dilakukan baik di dalam negeri maupun luar negeri. Beberapa penelitian tentang ketimpangan di Indonesia menunjukkan bahwa ketimpangan semakin meningkat sejak Tahun 2001, terutama antara Pulau Jawa dan pulau-pulau diluar Pulau Jawa (Rahmadi \& Parmadi, 2019:56). Badan Pusat Statistik melakukan perhitungan ketimpangan dengan menggunakan Indeks Ratio Gini dan hasil menunjukkan bahwa selama periode 2005-2019 kondisi ketimpangan pendapatan Indonesia semakin memburuk. Kondisi tersebut ditandai dengan meningkatnya koefisien Gini dari 0,355 pada Tahun 2005 menjadi 0,380 di Tahun 2019. Hal yang sama dilakukan oleh Putri \& Dartanto (2016:74) yang melakukan studi ketimpangan dengan menggunakan metode dekomposisi Indeks Theil's L atau Mean Logaritmic Deviation (MLD). Hasil studi menunjukkan bahwa selama periode 2005-2011 di Indonesia terjadi peningkatan ketimpangan pada tiap-tiap subgrup, sedangkan pada periode 2011-2014 terjadi peningkatan pendapatan populasi di perkotaan. Iswanto (2015:47-51) melakukan studi serupa dengan menggunakan metode analisis LQ, Shift Share, Tipologi Sektoral, Tipologi Klassen, Indeks Williamson, Indeks Theil, Korelasi Pearson dan Uji Hipotesis Kuznetzs. Hasil studi menunjukkan bahwa disparitas pendapatan antarwilayah di Provinsi Jawa Timur meningkat dan Hipotesis Kuznets tidak berlaku di wilayah ini. Tidak jauh berbeda dengan Yasa \& Arka (2015:65) yang melakukan penelitian untuk mengetahui hubungan antara pertumbuhan ekonomi dan disparitas pendapatan antarwilayah di Provinsi Bali dengan menggunakan analisis Indeks Williamson dan analisis jalur. Hasil analisis menunjukkan bahwa disparitas pendapatan antarwilayah selama periode 2001-2012 tergolong rendah dan pertumbuhan ekonomi berpengaruh negatif terhadap disparitas pendapatan. Sementara itu dari luar negeri, Chadha \& Nandwani (2018:365) melakukan studi serupa dengan tujuan untuk mengetahui ketimpangan pengeluaran konsumsi di India dan hubungan antara ketimpangan horizontal dan pertumbuhan ekonomi. Dengan menggunakan analisis Indeks Gini dan Indeks Entropi Theil, hasil studi menunjukkan bahwa ketimpangan di 18 Negara bagian India selama Tahun 19882004 cenderung meningkat, sementara hasil regresi linier membuktikan bahwa terdapat hubungan yang lemah antara ketimpangan horizontal dan pertumbuhan ekonomi.

Penelitian yang berkaitan dengan pergeseran struktur ekonomi di dalam negeri dilakukan oleh Mardiana et al., (2017:421-425) yang melakukan studi di Provinsi Bali selama periode 2010-2015 dengan menggunakan analisis Shift Share, LQ, MRP, Overlay, dan Tipologi Klassen. Hasil studi menunjukkan bahwa di Kabupaten Tabanan telah terjadi pergeseran peranan sektor-sektor ekonomi yang ditandai dengan semakin besarnya peran sektor jasa dan industri dibanding peran sektor pertanian. Tidak berbeda dengan Nasaruddin et al., (2020:41) yang melakukan penelitian tentang sektor basis dan pergeseran struktur ekonomi menggunakan analisis Location Quotient dan Shift Share. Hasil studi menunjukkan bahwa perekonomian Kabupaten Maros selama periode 2014-2018 tidak mengalami pergeseran. Peneliti dari luar negeri, yaitu Cheong \& Wu (2014:341) juga melakukan studi serupa untuk membuktikan adanya keterkaitan antara pergeseran struktur ekonomi dan ketimpangan antarwilayah di Cina menggunakan analisis Indeks Gini. Hasil penelitian menunjukkan bahwa selama kurun waktu 1997-2010 ketimpangan di wilayah timur, tengah dan timur laut di Cina cenderung meningkat, sedangkan ketimpangan di wilayah barat Cina cenderung menurun. Sektor sekunder memberi kontribusi terbesar terhadap ketimpangan antarwilayah di Cina yang disebabkan oleh ketidakmerataan distribusi nilai tambah industri. 


\section{METODE}

Jenis penelitian ini adalah penelitian kuantitatif deskriptif yang dilakukan terhadap 56 kabupaten/kota dengan periode amatan Tahun 2012-2019. Data yang digunakan dalam penelitian ini adalah data sekunder yang diperoleh dari BPS, meliputi PDRB, pertumbuhan ekonomi, jumlah penduduk, dan PDRB per kapita kabupaten/kota. Data diolah dengan menggunakan teknik analisis data berupa Indeks Williamson, Indeks Entropi Theil, Korelasi Pearson, Hipotesis Kuznets dan analisis Shift Share.

\section{Indeks Williamson dan Indeks Entropi Theil}

Untuk mengetahui trend ketimpangan antarwilayah di Kalimantan atau menjawab tujuan penelitian pertama, digunakan Indeks Williamson yang merupakan salah satu metode untuk mengukur ketimpangan antarwilayah. Indeks Williamson diperkenalkan oleh Jeffrey G. Williamson pada Tahun 1965 dalam bentuk model Vw atau indeks tertimbang dan Vuw atau indeks tidak tertimbang untuk mengukur tingkat kesenjangan pendapatan per kapita suatu negara pada waktu tertentu. Adapun formulasi dari Indeks Williamson adalah sebagai berikut (Williamson, 1965:11):

$$
\mathrm{IW}=\frac{\sqrt{\sum_{i=1}^{n}\left(\mathrm{Y}_{\mathrm{i}}-\mathrm{Y}\right)^{2} \cdot \frac{\mathrm{f}_{\mathrm{i}}}{n}}}{Y}
$$

di mana:

IW = Indeks Williamson;

$\mathrm{Y}_{\mathrm{i}}=$ PDRB per kapita kabupaten/kota $\mathrm{i}$;

$\mathrm{Y}=$ PDRB per kapita Pulau Kalimantan;

$\mathrm{f}_{\mathrm{i}}=$ jumlah penduduk kabupaten/kota $\mathrm{i}$

$\mathrm{n}=$ jumlah penduduk Pulau Kalimantan.

Nilai Indeks Williamson (IW) berkisar antara 0 sampai 1 dengan ketentuan sebagai berikut: (a) jika nilai IW < 0,3 maka ketimpangan antarwilayah tergolong rendah, yang berarti bahwa pembangunan antarwilayah merata; (b) jika nilai IW antara 0,3 sampai 0,5, maka ketimpangan antarwilayah tergolong sedang; dan (c) jika nilai IW $>0,5$ atau mendekati satu maka ketimpangan antarwilayah semakin melebar atau tinggi, artinya bahwa pembangunan antarwilayah tersebut tidak merata. Namun, jika nilai IW lebih dari 1 maka pada wilayah tersebut terjadi ketimpangan yang sangat tinggi.

Untuk menjawab tujuan penelitian kedua, yaitu mengetahui mengetahui kesenjangan antarwilayah (between-region inequality) dan kesenjangan dalam satu wilayah (within-region inequality), digunakan Indeks Entropi Theil (IET). Indeks ini tidak memiliki batas atas atau batas bawah, namun, apabila nilai IET semakin besar maka wilayah tersebut semakin timpang, sebaliknya jika nilai IET semakin kecil maka pembangunan antarwilayah semakin merata.

Indeks Entropi Theil diperkenalkan oleh Henri Theil pada Tahun 1967 mempunyai kelebihan dibandingkan dengan indeks konsentrasi spasial yang lain, yang mana pada suatu titik waktu, indeks ini menyediakan ukuran derajat konsentrasi distribusi spasial pada sejumlah daerah dan subdaerah dalam suatu negara. Ketimpangan antarwilayah yang dihitung dengan Indeks Entropi Theil diformulasikan sebagai berikut (Theil, 1979:99):

di mana:

$$
\mathrm{IC}=\sum_{i=1}^{n} \frac{G D P_{i}}{G D P_{u}} \times \log \frac{Y_{i}}{\mathrm{Y}}=I C_{B G}+I C_{W G}
$$

$\mathrm{IC}=$ Indeks Entropi Theil;

$\mathrm{GDP}_{\mathrm{i}} \quad=$ PDRB kabupaten/kota $\mathrm{i}$;

$\mathrm{GDP}_{\mathrm{u}} \quad=$ PDRB Pulau Kalimantan;

$Y_{i}=$ PDRB per kapita kabupaten/kota $\mathrm{i}$;

$\mathrm{Y}=\mathrm{PDRB}$ per kapita Pulau Kalimantan; 
$\mathrm{IC}_{\mathrm{BG}}=$ Indeks Entropi Theil Between Group;

$\mathrm{IC}_{\mathrm{WG}}=$ Indeks Entropi Theil Within Group.

\section{Uji Korelasi Pearson}

Ukuran tingkat perkembangan suatu wilayah dan ukuran keberhasilan suatu pembangunan identik dengan tingkat pertumbuhan ekonomi yang dipresentasikan dengan perubahan PDRB (Raafi'i et al., 2018:245). Hubungan antara variabel pertumbuhan ekonomi dan PDRB per kapita dengan Indeks Williamson dan Indeks Entropi Theil dapat diketahui dengan melakukan uji Korelasi Pearson dengan formulasi sebagai berikut:

$$
\mathrm{r}_{\mathrm{xy}}=\frac{n \sum_{i=1}^{n} X_{\mathrm{i}} Y_{\mathrm{i}}-\left(\sum_{i=1}^{n} X_{\mathrm{i}}\right)\left(\sum_{i=1}^{n} Y_{\mathrm{i}}\right)}{\sqrt{\left[n \sum_{i=1}^{n} X_{\mathrm{i}}{ }^{2}-\left(\sum_{i=1}^{n} X_{\mathrm{i}}\right)^{2}\right]} \sqrt{\left[n \sum_{i=1}^{n} Y_{\mathrm{i}}{ }^{2}-\left(\sum_{i=1}^{n} Y_{\mathrm{i}}\right)^{2}\right]}}
$$

di mana:

$\mathrm{r}_{\mathrm{xy}}=$ koefisien korelasi;

$\mathrm{X}_{\mathrm{i}}=$ indeks ketimpangan $\mathrm{a}$;

$\mathrm{Y}_{\mathrm{i}}=$ indeks ketimpangan $\mathrm{b}$

$\mathrm{n}=$ jumlah observasi.

Koefisien korelasi berada dalam range $-1 \leq \mathrm{r} \leq 1$. Apabila nilai $\mathrm{r}=-1$ atau mendekati -1 , maka hubungan dua variabel adalah sempurna atau kuat sekali, tetapi negatif. Hubungan tersebut bersifat berlawanan, jika nilai variabel yang satu turun, maka nilai variabel yang lain akan naik atau sebaliknya. Jika nilai $\mathrm{r}=1$ atau mendekati 1 maka hubungan dua variabel bersifat positif dan memiliki arah hubungan yang searah. Artinya, apabila nilai variabel yang satu mengalami kenaikan, maka nilai variabel lain akan naik. Namun, nilai $r=0$ atau mendekati 0 maka hubungan dua variabel sangat lemah atau tidak ada hubungan sama sekali. Interval hubungan korelasi antar variabel dijabarkan oleh Sujarweni (2015) dalam Sarkawi et al., (2018:131) sebagaimana ditunjukkan pada tabel berikut.

\begin{tabular}{cl} 
Tabel 1. Interpretasi Koefisien Korelasi Pearson \\
\hline $\begin{array}{c}\text { Interval } \\
\text { Koefisien }\end{array}$ & Tingkat Hubungan \\
\hline $0,00-0,20$ & Sangat Lemah \\
$0,21-0,40$ & Lemah \\
$0,41-0,70$ & Kuat \\
$0,71-0,90$ & Sangat Kuat \\
$0,91-0,99$ & Kuat Sekali \\
1 & Sempurna \\
\hline
\end{tabular}

Sumber: Sujarweni (2015)

Untuk menjawab tujuan penelitian ketiga, yaitu mengetahui hubungan antara variabel pertumbuhan ekonomi dan PDRB per kapita dengan ketimpangan wilayah, digunakan teknik analisis regresi linier berganda dengan menggunakan uji hipotesis yang terdiri dari uji t, uji $F$ dan uji $\mathrm{R}^{2}$. Adapun model persamaan yang digunakan sebagai berikut:

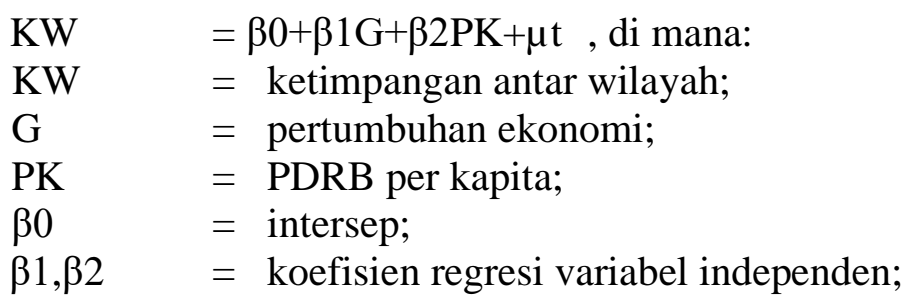


$\mu \quad=$ error term;

$\mathrm{t} \quad=$ time series.

\section{Hipotesis Kuznets}

Untuk mengetahui Hipotesis Kuznets berlaku atau tidak di Kalimantan atau menjawab tujuan keempat, dapat dibuktikan dengan membuat grafik antara ketimpangan wilayah (Indeks Williamson) dan pertumbuhan ekonomi dan pendapatan per kapita. Hipotesis Kuznets yang ditemukan oleh Kuznets pada Tahun 1955 menjelaskan hubungan antara ketimpangan wilayah dan pertumbuhan ekonomi dalam bentuk kurva $U$ terbalik (Kuznets, 1955:27). Kuznets menyatakan bahwa pada awal pertumbuhan, ketimpangan akan memburuk dan pada tahap berikutnya ketimpangan akan menurun, tetapi pada waktu tertentu ketimpangan akan meningkat lagi dan pada akhirnya menurun. Uji Hipotesis Kuznets dapat dilakukan dengan menggunakan regresi kuadratik, yaitu membuat plot grafik antara pertumbuhan ekonomi dengan indeks ketimpangan. Hipotesis Kuznets akan berlaku jika plot data dibuat dalam grafik dengan sebaran nonlinier membentuk huruf $U$.

\section{Analisis Shift Share}

Untuk menjawab tujuan penelitian terakhir, yaitu menganalisis pergeseran struktur ekonomi di Kalimantan, digunakan analisis Shift Share. Analisis ini pertama kali diperkenalkan oleh Perloff et., al pada Tahun 1960 yang bertujuan untuk mengetahui perubahan struktur ekonomi dan pergeseran sektor perekonomian pada suatu wilayah. Komponen utama dalam analisis Shift Share meliputi: (1) komponen pertumbuhan nasional atau National Share $\left(\mathrm{N}_{\mathrm{ij}}\right)$, menunjukkan pengaruh pertumbuhan ekonomi nasional terhadap perekonomian daerah; (2) komponen pergeseran proporsional (Propotional Shift $/ \mathrm{P}_{\mathrm{ij}}$ ) atau disebut juga dengan bauran industri (industry mix), menunjukkan perubahan relatif kinerja suatu sektor pada daerah tertentu terhadap sektor yang sama di tingkat atasnya; dan (3) pergeseran diferensial (Differential Shift/ $\mathrm{D}_{\mathrm{ij}}$ ) atau keunggulan kompetitif, menentukan daya saing industri daerah terhadap perekonomian yang dijadikan acuan. Jika pergeseran diferensial dari suatu industri adalah positif, daya saing industri tersebut lebih tinggi daripada industri yang sama terhadap perekonomian yang dijadikan acuan.

Rumus matematis yang digunakan pada analisis Shift Share adalah sebagai berikut (Knudsen \& Barff, 1991:422) :

$$
\begin{aligned}
& D_{i j}=N_{i j}+P_{i j}+C_{i j} \\
& N_{i j}=E_{i j} \times r_{n} \\
& P_{i j}=E_{i j} \times\left(r_{i n}-r_{n}\right) \\
& C_{i j}=E_{i j} \times\left(r_{i j}-r_{i n}\right) \\
& \text { di mana: }
\end{aligned}
$$

Eij = output sektor i daerah j;

rij = laju pertumbuhan sektor i daerah $\mathrm{j}$;

rin = laju pertumbuhan sektor i nasional;

$\mathrm{rn} \quad=$ laju pertumbuhan ekonomi nasional.

Untuk menentukan kuat lemahnya suatu sektor ekonomi, digunakan kategori Enders dengan klasifikasi sebagai berikut (Wiwekananda \& Utama, 2016:41): (1) sektor sangat kuat, jika nilai industri mix (Proportional Shift) dan pangsa daerah $\left(\mathrm{C}_{\mathrm{ij}}\right)$ positif; (2) sektor kuat, jika nilai positif industri mix melebihi nilai negatif pangsa daerah; (3) sektor agak kuat, jika nilai positif pangsa daerah melebihi nilai negatif industri mix; (4) sektor agak lemah, jika nilai negatif industri mix melebihi nilai positif pangsa daerah; (5) sektor lemah, jika nilai negatif pangsa daerah melebihi nilai positif industri mix; dan (6) sektor sangat lemah, jika nilai industri mix dan pangsa daerah negatif. 


\section{HASIL DAN PEMBAHASAN}

PDRB per kapita merupakan salah satu indikator ekonomi untuk mengukur tingkat kesejahteraan penduduk suatu wilayah. Jika semakin besar PDRB per kapita suatu wilayah maka semakin baik tingkat kesejahteraan masyarakat pada wilayah tersebut, begitu pula sebaliknya. Perbedaan PDRB per kapita antarwilayah memberikan gambaran tentang perbedaan perkembangan pembangunan. Secara keseluruhan pendapatan per kapita kabupaten/kota di Provinsi Kalimantan Timur lebih tinggi dibandingkan dengan kabupaten/kota di empat provinsi lain. Hal ini tidak terlepas bahwa Provinsi Kalimantan Timur memiliki potensi sumber daya alam yang sangat berlimpah terutama minyak, gas alam, dan batu bara. Keadaan tersebut membuat daerah-daerah di Provinsi Kalimantan Timur memiliki pendapatan per kapita tertinggi se-Kalimantan, terutama masyarakat di Kabupaten Kutai Timur dan Kota Bontang. Tingginya nilai PDRB per kapita kedua wilayah tersebut disebabkan oleh peranan dan kontribusinya yang sangat besar bagi perekonomian provinsi dan nasional. Kota Bontang dikenal sebagai kota penghasil gas alam cair, batubara serta urea dan amoniak, sedangkan Kabupaten Kutai Timur merupakan daerah penghasil batubara terbesar di Indonesia. Sementara wilayah yang memiliki nilai PDRB per kapita terendah mayoritas berada di Kalimantan Barat dengan rata-rata pendapatan per kapita dibawah rata-rata pendapatan per kapita Kalimantan. Rendahnya PDRB per kapita disebabkan karena daerah-daerah tersebut tidak memiliki potensi sumberdaya alam melimpah dan kondisi sarana infastrukturnya masih terbatas. Salah satunya adalah Kabupaten Melawi, merupakan daerah pemekaran yang dibentuk pada Tahun 2003. Sebagian besar wilayahnya merupakan daerah perbukitan dengan pendapatan per kapita sangat rendah dan tingkat kemiskinan yang sangat tinggi.

\section{Analisis Indeks Williamson dan Entropi Theil}

Perbedaan nilai PDRB per kapita yang sangat mencolok akan menimbulkan perbedaan kesejahteraan antarmasyarakat dan tidak meratanya distribusi pendapatan antarwilayah. Dampak terbesar dari perbedaan proses pembangunan dan kondisi demografi wilayah berujung pada timbulnya ketimpangan. Sjafrizal (1997) mengungkapkan bahwa ketimpangan pembangunan antarwilayah dipicu oleh perbedaan potensi daerah yang sangat besar, kondisi demografis dan ketenagakerjaan, serta perbedaan kondisi sosial budaya

antarwilayah. Untuk mengetahui kondisi ketimpangan antarkabupaten/kota di Kalimantan, digunakan analisis Indeks Williamson dan Indeks Entropi Theil.

Gambar 1. Ketimpangan Kabupaten/Kota Di Kalimantan Tahun 2012-2019

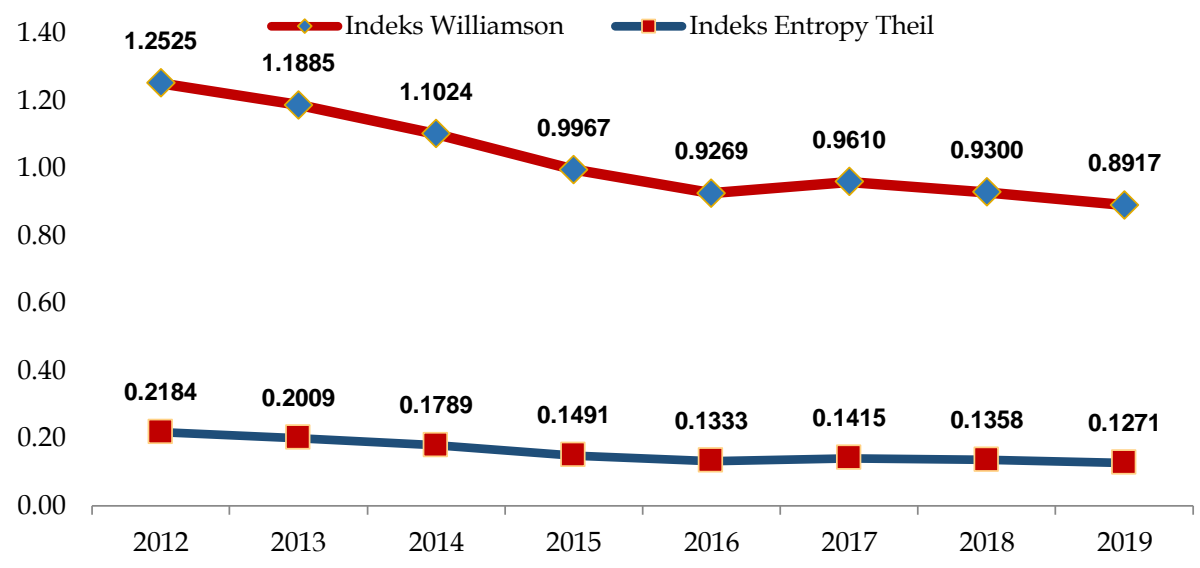

Sumber: BPS, 2012-2019 (diolah)

Nilai Indeks Williamson dan Indeks Entropi Theil sebagaimana terlihat pada Gambar 1 menunjukkan bahwa kondisi ketimpangan antarkabupaten/kota di Kalimantan berfluktuatif dengan trend menurun. Ketimpangan tersebut tergolong dalam kategori tinggi atau dengan kata 
lain distribusi pendapatan kabupaten/kota di Kalimantan tidak merata. Ketimpangan tertinggi terjadi pada Tahun 2012, yaitu 1,2525 dan terus menurun hingga mencapai 0,9269 pada Tahun 2016. Pada Tahun 2017, angka ketimpangan sempat meningkat, tetapi akhirnya menurun pada Tahun 2019.

Indeks Entropi Theil dalam penelitian ini tidak hanya dihitung secara total, tetapi juga dihitung Indeks Entropi Theil Between Group dan Within Group. Indeks Entropi Theil Between Group bertujuan untuk mengetahui gambaran ketimpangan yang terjadi antarprovinsi, sedangkan Indeks Entropi Theil Within Group digunakan untuk mengetahui gambaran ketimpangan yang terjadi di dalam provinsi. Hasil perhitungan Indeks Entropi Theil Between Group dan Within Group pada Tabel 2 menunjukkan bahwa ketimpangan antarprovinsi dan dalam provinsi di Kalimantan cenderung menurun.

Tabel 2. Indeks Entropi Theil, Between Group, dan Within Group, 2012--2019

\begin{tabular}{|c|c|c|c|c|c|c|c|c|}
\hline \multirow[b]{2}{*}{ Tahun } & \multirow{2}{*}{$\begin{array}{c}\text { Indeks } \\
\text { Entropi } \\
\text { Theil }\end{array}$} & \multirow{2}{*}{$\begin{array}{l}\text { Indeks } \\
\text { Entropi Theil } \\
\text { Between } \\
\text { Group }\end{array}$} & \multirow{2}{*}{$\begin{array}{l}\text { Total } \\
\text { Within } \\
\text { Group }\end{array}$} & \multicolumn{5}{|c|}{ Indeks Entropi Theil Within Group } \\
\hline & & & & $\begin{array}{l}\text { Prov. } \\
\text { Kalbar }\end{array}$ & $\begin{array}{c}\text { Prov. } \\
\text { Kalteng }\end{array}$ & $\begin{array}{l}\text { Prov. } \\
\text { Kalsel }\end{array}$ & $\begin{array}{l}\text { Prov. } \\
\text { Kaltim }\end{array}$ & $\begin{array}{c}\text { Prov. } \\
\text { Kaltara }\end{array}$ \\
\hline 2012 & 0 & 0,15563 & נו & 0,00169 & 0,00093 & 0,00684 & 0,05277 & 0,00058 \\
\hline 2013 & 0,20089 & 0,14402 & 0,05687 & 0,00183 & 0,00088 & 0,00672 & 0,04694 & 0,00050 \\
\hline 2014 & 0,17888 & 0,12972 & 0,04916 & 0,00191 & 0,00078 & 0,00649 & 0 & 0,00039 \\
\hline 2015 & 0,14906 & 0,10727 & 0,04 & 0,00210 & 0,00073 & 0,00580 & 0,03282 & 0,00035 \\
\hline 2016 & 0,13328 & 0,09600 & 0,03727 & 0,00220 & 0,00073 & 0,00534 & 0,02868 & 0,00033 \\
\hline 2017 & 0,14154 & 0,10216 & 0,03938 & 0,00218 & 0,00071 & 0,00498 & 0,03125 & 0,00025 \\
\hline 2018 & 0,13582 & 0,09924 & 0,03657 & 0,00218 & 0,00073 & 0,00481 & 0,02863 & 0,00022 \\
\hline 2019 & 0,12711 & 0,09330 & 0,03381 & 0,00225 & 0,00072 & 0,00452 & 0,02612 & 0,00020 \\
\hline $\begin{array}{l}\text { Rata- } \\
\text { rata }\end{array}$ & 0,16063 & 0,11592 & 0,04471 & 0,00204 & 0,00078 & 0,00569 & 0,03585 & 0,00035 \\
\hline
\end{tabular}

Sumber: BPS, 2012-2019 (diolah)

Ketimpangan antarwilayah di Kalimantan lebih diakibatkan oleh ketimpangan antar provinsi (between provinces inequality) yang menyumbang 72,17 persen terhadap ketimpangan total. Provinsi yang berkontribusi besar terhadap ketimpangan antarwilayah di Kalimantan adalah Kalimantan Timur. Nilai ketimpangan antar kabupaten/kota wilayah di provinsi yang kaya akan sumberdaya alam tersebut merupakan tertinggi se-Kalimantan, yaitu 0,55621. Kondisi tersebut disebabkan oleh tingginya perbedaan antara nilai PDRB per kapita tertinggi (Kota Bontang) dan terendah (Hulu Sungai Utara) dengan perbandingan 1:19.

Untuk mengetahui hubungan atau pengaruh pertumbuhan ekonomi dan PDRB per kapita terhadap ketimpangan antarwilayah, dilakukan analisis regresi linier berganda. Model regresi yang diestimasi harus memenuhi asumsi klasik dan bersifat BLUE (Best Linear Unbiased Estimatori). Estimator bersifat best, artinya memiliki varians minimum, bersifat linier terhadap variabel terikat dan unbiased, yaitu nilai estimator mendekati nilai populasi (Latuconsina, 2017:207). Model regresi yang baik harus memenuhi beberapa uji asumsi klasik, yaitu: (1) uji normalitas, untuk melihat distribusi normal dari nilai residual; (2) uji multikolinearitas, untuk mengetahui korelasi yang tinggi antarvariabel bebas; (3) uji heteroskedastisitas, mengetahui ketidaksamaan variasi error yang konstan pada variabel bebas; dan (4) uji autokorelasi, untuk melihat adanya korelasi antara suatu periode $t$ dengan periode sebelumnya $(t-1)$. Sedangkan untuk mengetahui pengaruh variabel bebas terhadap variabel terikat, dapat dilakukan uji signifikansi parsial (uji t), uji simultan (uji F) dan uji $R^{2}$. 


\section{Uji Normalitas}

Uji normalitas dilakukan untuk mengetahui apakah error term mendekati distribusi normal atau tidak, salah satunya dengan menggunakan uji Jarque-Bera (JB). Jika nilai probabilitas Jarque-Bera lebih besar dari 0,05, data berdistribusi normal, begitu juga sebaliknya. Hasil uji Jarque-Bera dengan menggunakan EViews sebagaimana terlihat pada Gambar 2 menunjukkan bahwa nilai probabilitas $>0,05$, artinya error term pada model regresi berdistribusi normal.

Gambar 2. Hasil Uji Jarque-Bera

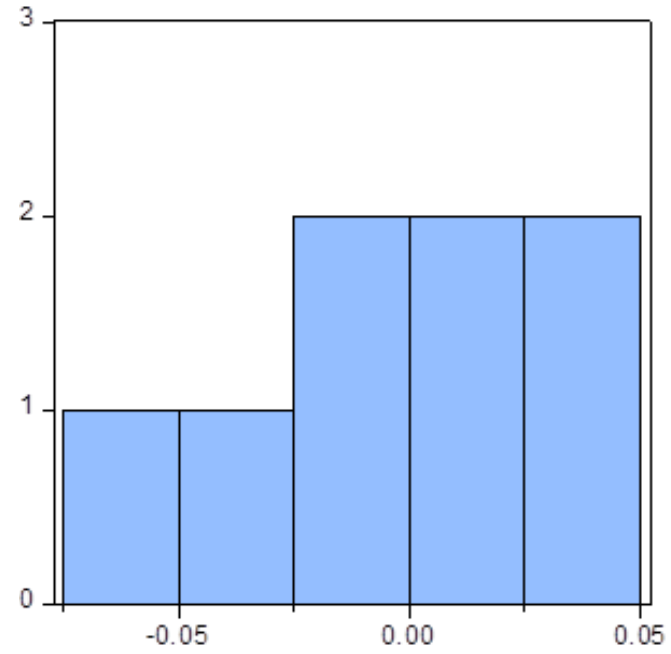

\begin{tabular}{|lc|}
\hline \multicolumn{2}{|l|}{ Series: Residuals } \\
Sample 2012 2019 \\
Observations 8 \\
Mean & $5.55 \mathrm{e}-17$ \\
Median & -0.000616 \\
Maximum & 0.046424 \\
Minimum & -0.051990 \\
Std. Dev. & 0.032522 \\
Skewness & -0.118332 \\
Kurtosis & 1.988192 \\
& \\
Jarque-Bera & 0.359922 \\
Probability & 0.835303 \\
\hline
\end{tabular}

Sumber: Hasil Pengolahan dengan Eviews 9

\section{Uji Multikolinearitas dan Heteroskedastisitas}

Multikolinearitas terjadi jika terdapat hubungan linier antarvariabel bebas dalam model regresi. Untuk menguji ada tidaknya multikolinieritas dalam sebuah model, dilakukan analisis korelasi antarvariabel dengan melihat nilai VIF (Variance Inflation Factor) dan tolerance. Jika nilai VIF lebih dari 10 dan nilai tolerence kurang dari 0,1 maka dalam model tersebut terjadi multikolinearitas.

Uji heteroskedastisitas pada model regresi bertujuan untuk mengetahui terjadinya ketidaksamaan varian dari residual dalam sebuah pengamatan. Model yang baik adalah bersifat homoskedastisitas atau tidak terjadi masalah heteroskedastisitas (Ghozali, 2014:134). Dalam penelitian ini, uji heterokedastisitas dilakukan dengan menggunakan uji Glejser, yang jika nilai probabilitas variabel bebas lebih besar 0,05 maka tidak terjadi masalah heteroskedastisitas pada model regresi. Hasil uji multikolinearitas dan uji heteroskedastisitas sebagaimana ditunjukkan pada Tabel 3 diperoleh bahwa model regresi dalam penelitian ini bebas dari masalah multikolinearitas (nilai $\mathrm{VIF}<10$ ) dan heterokedastisitas (nilai probabilitas variabel bebas $>0,05)$.

Tabel 3. Hasil Uji Multikolinearitas dan Uji Glejser

\begin{tabular}{lcrr}
\hline \multicolumn{1}{c}{ Variabel } & Centered VIF & Tolerence & Probabilitas \\
\hline PDRB Per Kapita (PK) & 1,045198 & 0,957 & 0.5685 \\
Pertumbuhan Ekonomi & 1,045198 & 0,957 & 0.8014 \\
(G) & NA & NA & 0.2970 \\
Konstanta (C) & \multicolumn{2}{c}{}
\end{tabular}




\section{Uji Autokorelasi}

Uji autokorelasi bertujuan untuk menguji apakah dalam suatu model regresi linier terdapat korelasi antara residual pada periode $t$ dan kesalahan pada periode t-1 (Ghozali, 2014:113). Model regresi yang baik adalah model yang tidak memiliki masalah autokorelasi atau tidak terdapat korelasi, salah satunya dengan menggunakan uji Durbin Watson (DW). Uji ini akan menghasilkan nilai DW yang nantinya akan dibandingkan dengan dua nilai DW Tabel, yaitu Durbin Upper (DU) dan Durbin Lower (DL). Suatu model regresi tidak memiliki masalah autokorelasi positif atau negatif jika nilai DW berada pada interval DU $<$ DW $<4$-DU. Hasil uji autokorelasi sebagaimana ditunjukkan pada Tabel 4 diperoleh bahwa nilai DW terletak antara DU dan 4-DU yang berarti bahwa tidak terdapat autokorelasi positif atau negatif dalam model regresi ini.

Tabel 4. Hasil Uji Autokorelasi

\begin{tabular}{lrcr}
\hline \multicolumn{1}{c}{ Variabel } & Coefficient & t-Statistic & \multicolumn{1}{c}{ Probabilitas } \\
\hline PDRB Per Kapita & -0.016025 & -8.197245 & 0.0004 \\
Pertumbuhan Ekonomi & 0.055014 & 5.167383 & 0.0036 \\
Konstanta (C) & 1.892507 & 14.73138 & 0.0000 \\
R-squared $\left(\mathrm{R}^{2}\right)$ & 0.940987 & Durbin-Watson stat & 2.180890 \\
F hitung & 39.86374 & Prob(F-statistic) & 0.000846 \\
t tabel & 2,57058 & DU & 1,7771 \\
F tabel & 5,876 & \multicolumn{2}{c}{} \\
\hline
\end{tabular}

Sumber: Hasil Pengolahan dengan Eviews 9

\section{Uji F dan uji t}

Uji $\mathrm{F}$ atau uji serentak bertujuan untuk melihat pengaruh variabel bebas secara simultan (bersama-sama) terhadap variabel terikat. Sedangkan uji t bertujuan untuk melihat pengaruh masing-masing variabel bebas secara parsial terhadap variabel terikat. Dalam uji F, jika nilai signifikasi $<0,05$ atau $\mathrm{F}$ hitung $>\mathrm{F}$ tabel maka terdapat pengaruh yang signifikan secara simultan antara variabel bebas terhadap variabel terikat. Namun, sebaliknya, jika nilai signifikansi $>0,05$ atau atau $\mathrm{F}$ hitung $<\mathrm{F}$ tabel maka tidak terdapat pengaruh yang signifikan antara variabel bebas secara simultan terhadap variabel terikat. Sedangkan dalam uji t, jika nilai signifikansi < 0,05 atau t hitung > t tabel, maka terdapat pengaruh antara variabel bebas terhadap variabel terikat secara parsial, begitu juga sebaliknya.

Untuk melihat hubungan antara variabel pertumbuhan ekonomi dan PDRB per kapita dengan ketimpangan antarwilayah baik secara simultan maupun parsial dalam studi ini, dilakukan perumusan hipotesis. Terdapat tiga hipotesis yang akan diuji dengan tingkat kepercayaan 95 persen, yaitu: (1) H1 = terdapat pengaruh variabel PDRB per kapita terhadap ketimpangan antar wilayah; (2) $\mathrm{H} 2$ = terdapat pengaruh variabel pertumbuhan ekonomi terhadap ketimpangan antar wilayah; dan (3) H3 = terdapat pengaruh variabel pertumbuhan ekonomi dan PDRB per kapita terhadap ketimpangan antar wilayah. Hasil uji F dan uji t dapat dilihat dari nilai probabilitas variabel pertumbuhan ekonomi dan PDRB per kapita (Tabel 4) kurang dari 0,05 serta nilai t hitung lebih besar dari t tabel. Sehingga dapat disimpulkan bahwa Hipotesis 1 dan Hipotesis 2 diterima, artinya variabel PDRB per kapita dan pertumbuhan ekonomi secara parsial atau masing-masing berpengaruh terhadap ketimpangan antarwilayah. Sedangkan untuk melihat hubungan variabel bebas secara simultan terhadap variabel terikat dapat dilihat dari nilai probabilitas yang kurang dari 0,05 dan nilai $\mathrm{F}$ hitung lebih besar dari $\mathrm{F}$ tabel. Hasil tersebut menyimpulkan bahwa Hipotesis 3 diterima, artinya variabel PDRB per kapita dan pertumbuhan ekonomi berpengaruh secara bersama-sama terhadap ketimpangan antar wilayah. 


\section{Uji Koefisien Determinasi $\left(\mathbf{R}^{2}\right)$}

Koefisien determinasi bertujuan untuk mengukur kemampuan model dalam menerangkan variasi variabel terikat (Ghozali, 2014:96). Nilai koefisien determinasi berada di antara nol dan satu. Jika nilai $\mathrm{R}^{2}$ kecil, artinya kemampuan variabel-variabel bebas dalam menjelaskan variasi variabel terikat sangat terbatas. Sedangkan jika nilai $\mathrm{R}^{2}$ mendekati satu, maka variabel-variabel bebas memberikan hampir semua informasi yang dibutuhkan untuk memprediksi variasi variabel terikat. Nilai koefisien determinasi pada studi ini sebesar 0,940987, artinya, pengaruh variabel PDRB per kapita dan pertumbuhan ekonomi secara simultan terhadap ketimpangan antarwilayah sebesar 94,0987 persen, sedangkan sisanya sebesar 5,9013 persen dijelaskan oleh faktor-faktor lain diluar model.

Berdasarkan hasil analisis uji regresi berganda diperoleh model persamaan regresi sebagai berikut: $\mathrm{KW}=1,892507-0,016025 \mathrm{PK}+0,055014 \mathrm{G}$. Nilai konstanta pada persamaan tersebut memiliki arti bahwa jika nilai variabel PDRB per kapita dan pertumbuhan ekonomi sama dengan nol maka tingkat ketimpangan antar wilayah di Kalimantan sebesar 1,892507. Sementara itu, nilai koefisien regresi pada variabel bebas atau slope menunjukkan besarnya pengaruh dari variabel bebas terhadap variabel tidak bebas (ceteris paribus). Tanda positif yang menyertai koefisien regresi memiliki arti bahwa arah perubahan variabel bebas dan variabel terikat berbanding lurus, begitu juga sebaliknya.

\section{Uji Korelasi Pearson}

Dalam penelitian ini, akan diuji hubungan antara variabel bebas (pertumbuhan ekonomi dan PDRB per kapita) dan variabel terikat (indeks ketimpangan) menggunakan uji korelasi Pearson. Hasil uji korelasi antara variabel PDRB per kapita dan indeks ketimpangan (lihat Tabel 5) diperoleh nilai signifikansi < 0,05, yang berarti bahwa terdapat hubungan yang kuat antara PDRB per kapita dan indeks ketimpangan. Hubungan tersebut bersifat negatif, yang mana setiap peningkatan pendapatan per kapita sebesar 1 persen akan menurunkan tingkat ketimpangan sebesar 0,016025 persen. Sementara itu, hasil uji korelasi antara variabel pertumbuhan ekonomi dengan indeks ketimpangan diperoleh nilai signifikansi $>0,05$. Artinya, hubungan positif antara variabel pertumbuhan ekonomi dengan indeks ketimpangan kurang kuat.

Walaupun variabel pertumbuhan ekonomi secara parsial berpengaruh lemah terhadap ketimpangan antarwilayah, tetapi secara bersama-sama, variabel PDRB per kapita dan pertumbuhan ekonomi secara signifikan memengaruhi ketimpangan antarwilayah. Hasil studi ini sama dengan hasil penelitian Yusica et.al., (2018:239) yang menemukan bahwa variabel pertumbuhan ekonomi secara parsial berpengaruh dan signifikan terhadap ketimpangan wilayah di Provinsi Kalimantan Timur. Hal ini didukung juga oleh Akanbi (2016:1) yang melakukan studi pada sembilan provinsi di Afrika Selatan selama periode 1995-2012. Hasil penelitiannya menunjukkan bahwa terdapat hubungan positif antara variabel pertumbuhan ekonomi dengan ketimpangan pendapatan, setiap peningkatan pertumbuhan ekonomi sebesar 1 persen akan meningkatkan ketimpangan pendapatan sebesar 0,25 persen. 
Tabel 5. Nilai Korelasi Pearson antara PDRB Per Kapita dan Pertumbuhan Ekonomi dengan Indeks Williamson dan Indeks Entropi Theil Tahun 2012-2019

\begin{tabular}{|c|c|c|c|}
\hline & & $\begin{array}{l}\text { PDRB Per } \\
\text { Kapita }\end{array}$ & $\begin{array}{l}\text { Pertumbuhan } \\
\text { Ekonomi }\end{array}$ \\
\hline \multirow{2}{*}{$\begin{array}{l}\text { Nilai Indeks } \\
\text { Williamson }\end{array}$} & $\begin{array}{l}\text { Pearson } \\
\text { Correlation }\end{array}$ & $-0,791^{*}$ & 0,385 \\
\hline & Sig. (2-tailed) & 0,019 & 0,347 \\
\hline \multirow{2}{*}{$\begin{array}{l}\text { Nilai Indeks Entropi } \\
\text { Theil }\end{array}$} & $\begin{array}{l}\text { Pearson } \\
\text { Correlation }\end{array}$ & $-0,769^{*}$ & 0,419 \\
\hline & Sig. (2-tailed) & 0,026 & 0,302 \\
\hline
\end{tabular}

Sumber: Hasil Pengolahan dengan SPSS

\section{Berlakunya Hipotesis Kuznets}

Untuk mengetahui apakah Hipotesis Kuznets berlaku atau tidak pada suatu wilayah, beberapa studi telah dilakukan, salah satunya oleh Melikhova \& Cizek (2014:388). Keduanya melakukan penelitian ketimpangan pendapatan dari 145 Negara selama periode 1979-2009 dengan menggunakan persamaan kuadratik logaritma. Hasil studi menemukan bahwa bentuk kurva U terbalik ditemukan di negara-negara dengan jumlah kontribusi sosial yang rendah. Pada penelitian ini, uji Hipotesis Kuznets juga menggunakan persamaan kuadratik logaritma (lihat Gambar 3), tetapi hubungan antara variabel bebas dan variabel terikat yang dinyatakan dalam bentuk kurva tidak berbentuk huruf U terbalik. Artinya, Hipotesis Kuznets tidak berlaku di Pulau Kalimantan. Hasil studi ini sama dengan yang dilakukan oleh Iswanto (2015) dan Nasr et.al., (2018). Dalam penelitiannya tentang ketimpangan pendapatan antarkabupaten/kota di Provinsi Jawa Timur, Iswanto (2015:65) menemukan bahwa Hipotesis Kuznets tidak berlaku di Jawa Timur. Sementara Nasr et al., (2018:841) melakukan studi dengan menggunakan data time series (Tahun 1917-2012) dan menemukan bahwa Hipotesis Kuznets tidak berlaku di Amerika Serikat.

Gambar 3. Kurva Hubungan Antara PDRB Per Kapita Dan Pertumbuhan Ekonomi Dengan Indeks Williamson Tahun 2012-2019
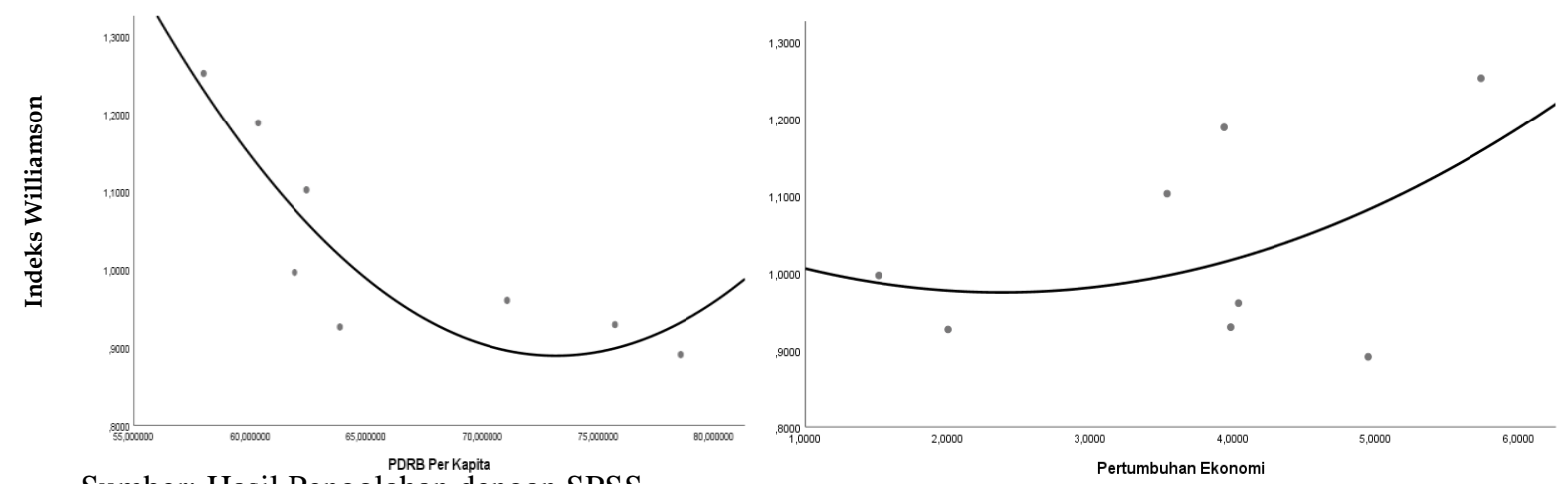

Sumber: Hasil Pengolahan dengan SPSS

\section{Analisis Shift Share}

Pulau Kalimantan merupakan pusat pembangunan di Indonesia Bagian Timur yang memiliki posisi strategis baik pada koridor nasional, regional ASEAN, dan internasional. Kalimantan memiliki potensi sumber daya alam yang sangat melimpah, seperti hasil pertambangan (minyak, gas, emas, dan batubara), kehutanan (kayu), perkebunan (sawit dan karet), serta perikanan laut dan darat. Kalimatan juga dikenal memiliki cadangan minyak gas bumi dan batubara terbesar serta kawasan hutan produksi terluas di Indonesia. Kondisi 
geografis dengan tingkat seismik yang rendah, membuat Kalimantan sangat baik untuk dijadikan lokasi cadangan penyangga bahan bakar minyak dan cadangan strategis minyak bumi (Renstra Direktorat Jenderal Minyak Dan Gas Bumi Tahun 2015-2019).

Tabel 6. Hasil Analisis Shift Share Tahun 2012-2019

\begin{tabular}{|c|c|c|c|c|}
\hline Sektor & $\begin{array}{l}\text { National Share } \\
(\mathrm{Rp})\end{array}$ & $\begin{array}{c}\text { Propotional Shift } \\
(\mathrm{Rp})\end{array}$ & $\begin{array}{c}\text { Competitive } \\
\text { Advantage (Rp) }\end{array}$ & Differential Shift \\
\hline $\begin{array}{l}\text { Pertanian, } \\
\text { Kehutanan, dan } \\
\text { Perikanan }\end{array}$ & 724.357.098,97 & $-228.157 .568,79$ & $258.781 .731,82$ & $754.981 .262,01$ \\
\hline $\begin{array}{l}\text { Pertambangan dan } \\
\text { Penggalian }\end{array}$ & $1.947 .980 .587,90$ & $-1.629 .158 .705,42$ & $520.066 .312,44$ & $838.888 .194,92$ \\
\hline $\begin{array}{l}\text { Industri } \\
\text { Pengolahan }\end{array}$ & $986.826 .063,75$ & $-225.688 .596,85$ & $-300.250 .694,60$ & $460.886 .772,31$ \\
\hline $\begin{array}{l}\text { Pengadaan Listrik } \\
\text { dan Gas }\end{array}$ & $3.500 .625,75$ & $-576.734,35$ & $4.705 .526,13$ & $7.629 .417,53$ \\
\hline $\begin{array}{l}\text { Pengadaan Air, } \\
\text { Pengelolaan } \\
\text { Sampah, Limbah } \\
\text { dan Daur Ulang }\end{array}$ & $6.420 .774,31$ & $-915.861,59$ & $779.190,69$ & $6.284 .103,42$ \\
\hline $\begin{array}{l}\text { Konstruksi } \\
\text { Perdagangan }\end{array}$ & $521.139 .744,55$ & $42.251 .520,59$ & $30.622 .968,50$ & $594.014 .233,64$ \\
\hline $\begin{array}{l}\text { Besar dan Eceran; } \\
\text { Reparasi Mobil } \\
\text { dan Sepeda Motor }\end{array}$ & $477.896 .541,03$ & $-104.840 .949,39$ & $210.963 .957,12$ & $584.019 .548,77$ \\
\hline $\begin{array}{l}\text { Transportasi dan } \\
\text { Pergudangan } \\
\text { Penyediaan }\end{array}$ & $258.614 .803,11$ & $64.023 .001,33$ & $17.760 .002,17$ & $340.397 .806,61$ \\
\hline $\begin{array}{l}\text { Akomodasi dan } \\
\text { Makan Minum }\end{array}$ & $80.372 .464,43$ & $-958.266,97$ & $27.691 .058,13$ & $107.105 .255,58$ \\
\hline $\begin{array}{l}\text { Informasi dan } \\
\text { Komunikasi }\end{array}$ & $110.246 .211,77$ & $74.803 .954,66$ & $4.174 .585,06$ & $189.224 .751,48$ \\
\hline $\begin{array}{l}\text { Jasa Keuangan } \\
\text { dan Asuransi }\end{array}$ & $133.208 .143,57$ & $30.609 .285,10$ & $-8.885 .438,89$ & $154.931 .989,79$ \\
\hline Real Estate & $87.724 .656,52$ & $-10.573 .359,86$ & $8.813 .938,41$ & $85.965 .235,08$ \\
\hline $\begin{array}{l}\text { Jasa Perusahaan } \\
\text { Administrasi }\end{array}$ & $16.700 .975,56$ & $7.751 .309,06$ & $-7.362 .236,02$ & $17.090 .048,60$ \\
\hline $\begin{array}{l}\text { Pemerintahan, } \\
\text { Pertahanan dan } \\
\text { Jaminan Sosial } \\
\text { Wajib }\end{array}$ & $225.831 .436,72$ & $-85.720 .972,40$ & $103.863 .621,61$ & $243.974 .085,93$ \\
\hline $\begin{array}{l}\text { Jasa Pendidikan } \\
\text { Jasa Kesehatan }\end{array}$ & $154.189 .494,43$ & $5.114 .023,99$ & $54.054 .320,44$ & $213.357 .838,85$ \\
\hline $\begin{array}{l}\text { dan Kegiatan } \\
\text { Sosial }\end{array}$ & $60.232 .592,86$ & $16.034 .169,53$ & $5.643 .158,05$ & $81.909 .920,43$ \\
\hline Jasa Lainnya & $44.311 .845,00$ & $18.539 .315,16$ & $-9.871 .117,55$ & $52.980 .042,62$ \\
\hline Total & $5.839 .554 .060,25$ & $-2.027 .464 .436,20$ & $921.550 .883,52$ & $4.733 .640 .507,57$ \\
\hline
\end{tabular}

Sumber: BPS, 2012-2019 (diolah)

Struktur perekonomian Kalimantan didominasi oleh sektor pertambangan dan penggalian, sektor industri pengolahan, dan sektor pertanian, kehutanan, dan perikanan. Selama delapan tahun terakhir, ketiga lapangan usaha tersebut memberi kontribusi terbesar terhadap 
perekonomian Kalimantan. Diantara ketiga sektor tersebut, kategori pertambangan dan penggalian merupakan sektor unggulan dan penyumbang terbesar bagi perekonomian Kalimantan. Namun, sejak tiga tahun terakhir, kontribusi sektor pertambangan semakin menurun dan pertumbuhannya melambat. Menurunnya peranan sektor tersebut khususnya subsektor pertambangan minyak, gas, dan panas bumi disebabkan oleh adanya penurunan produksi pertambangan bijih logam serta minyak gas dan panas bumi akibat sumur pengeboran minyak yang sudah tua dan belum adanya penambahan eksploitasi sumur baru serta rendahnya permintaan batubara di pasar global. Sementara itu, pada kondisi yang berbeda, pertumbuhan sektor industri pengolahan justru mengalami peningkatan. Keadaan tersebut mengindikasikan bahwa perekonomian Kalimantan mengalami perubahan struktur atau terjadi pergeseran. Perubahan struktur ekonomi yang terjadi akan dijelaskan dengan melihat pergeseran kontribusi sektoral perekonomian menurut lapangan usaha yang terdiri dari 17 (tujuh belas) sektor.

Hasil analisis Shift Share diperoleh bahwa kinerja perekonomian Kalimantan selama periode 2012-2019 mengalami perkembangan sebesar Rp4.733.640.507,57. Perkembangan tersebut lebih banyak dipengaruhi oleh peranan nasional dan keunggulan kompetitif, sedangkan peranan bauran industri cenderung melambat. Hasil analisis tersebut juga menunjukkan bahwa terdapat empat sektor yang tergolong dalam sektor sangat kuat dan memiliki daya saing kompetitif, yaitu sektor transportasi dan pergudangan, sektor jasa pendidikan, sektor informasi dan komunikasi, serta sektor jasa kesehatan dan kegiatan sosial.

Selama kurun waktu 2012-2019, sektor pertanian masih memberikan kontribusi positif terhadap PDRB Kalimantan (lihat Tabel 7). Sektor pertanian tergolong dalam sektor agak kuat dan menjadi andalan perekonomian bagi 25 kabupaten di Kalimantan, khususnya di Provinsi Kalimantan Barat dan Kalimantan Tengah. Sedangkan sektor pertambangan dan penggalian, walaupun kontribusinya paling tinggi, sektor ini tergolong dalam sektor agak lemah. Sementara sektor industri pengolahan yang tergolong dalam sektor sangat lemah, kontribusinya masih cukup tinggi dibanding duabelas sektor lain dan secara keseluruhan memiliki perkembangan terbesar dibanding sektor pertanian dan jasa. Perbedaaan perkembangan tersebut menunjukkan bahwa perekonomian Kalimantan mengalami perubahan struktural atau pergeseran dari sektor pertanian ke sektor industri. Hasil studi ini tidak jauh berbeda dengan penelitian Omolara (2019:205) yang menemukan bahwa perekonomian Nigeria selama periode 1991-2017 mengalami pergeseran dari sektor ekonomi ke sektor pelayanan (transportasi, komunikasi, perdagangan distributif, hotel dan restoran, keuangan dan asuransi, serta lainnya).

Salah satu penyebab menurunnya peranan pertanian, kehutanan, dan perikanan adalah berkurangnya luas lahan pada beberapa daerah di Kalimantan yang menyebabkan produktivitas menurun dan lambatnya kenaikan harga produk pertanian. Keadaan tersebut berimbas pada naiknya peranan industri. Hal ini sesuai dengan pernyataan Todaro (2006) yang menyatakan bahwa pertumbuhan ekonomi atau pembangunan daerah akan menyebabkan pergeseran struktur ekonomi. Pergeseran struktural secara perlahan akan menyebabkan peralihan dari sektor pertanian ke sektor non pertanian yang dicerminkan dengan naiknya peranan sektor nonpertanian dan menurunnya peranan sektor pertanian. Teori pembangunan Arthur Lewis juga menyatakan bahwa jika terjadi pergeseran struktur ekonomi maka sektor pertanian akan semakin ditinggalkan, karena sebagian besar tenaga kerja pada sektor pertanian akan mulai beralih ke sektor yang lebih modern, seperti sektor industri yang memberikan pendapatan yang lebih tinggi. 
Tabel 7. Rata-Rata Hasil Analisis Shift Share Sektor Pertanian, Industri dan Jasa Tahun 2012--2019

\begin{tabular}{clr}
\hline No. & \multicolumn{1}{c}{ Sektor } & \multicolumn{1}{c}{$\begin{array}{c}\text { Rata-Rata } \\
\text { Differential Shift }\end{array}$} \\
\hline 1. & $\begin{array}{l}\text { Pertanian (secara umum) } \\
\text { 754.981.262,01 }\end{array}$ & $\begin{array}{l}\text { Industri (pertambangan dan penggalian, industri pengolahan, } \\
\text { pengadaan listrik dan gas, pengadaan air, pengelolaan } \\
\text { sampah, limbah dan daur ulang, dan konstruksi) }\end{array}$ \\
& $\begin{array}{l}\text { Jasa (Perdagangan Besar dan Eceran, Transportasi dan } \\
\text { Pergudangan, Penyediaan Akomodasi dan Makan Minum, }\end{array}$ \\
& $\begin{array}{l}\text { Informasi dan Komunikasi, Jasa Keuangan dan Asuransi, } \\
\text { Real Estate, Jasa Perusahaan, Administrasi Pemerintahan, }\end{array}$ \\
& $\begin{array}{l}\text { Jasa Pendidikan, Jasa Kesehatan dan Kegiatan Sosial, dan } \\
\text { Jasa Lainnya }\end{array}$ & $1.486 .936 .974,98$ \\
\hline
\end{tabular}

\section{KESIMPULAN}

Hasil analisis Indeks Williamson dan Indeks Entropi Theil pada studi ini menunjukkan bahwa kondisi ketimpangan di Kalimantan selama periode penelitian tergolong dalam kategori tinggi dengan tren menurun. Hasil studi ini serupa dengan studi Ye et al., (2017:14) yang menemukan bahwa ketimpangan regional di Chongqing, Cina terus menurun selama periode 1997-2015. Kondisi tersebut terlihat dari nilai koefisien Gini yang semakin menurun dari 0,2936 pada Tahun 1997 menjadi 0,1998 pada Tahun 2015. Sementara itu, ketimpangan antar wilayah di Kalimantan lebih disebabkan oleh ketimpangan antar provinsi (between provinces inequality) dengan kontributor terbesar adalah Provinsi Kalimantan Timur.

Pada studi ini, variabel yang memengaruhi ketimpangan antarwilayah di Kalimantan adalah variabel PDRB per kapita sebagaimana ditunjukkan dengan kuatnya hubungan negatif kedua variabel tersebut. Sedangkan hubungan variabel pertumbuhan ekonomi dengan indeks ketimpangan kurang kuat walaupun secara simultan variabel pertumbuhan ekonomi berpengaruh terhadap ketimpangan antar wilayah. Hal tersebut menyebabkan Hipotesis Kuznets tidak berlaku di Pulau Kalimantan. Sementara hasil analisis Shift Share pada penelitian ini menunjukkan bahwa perekonomian Kalimantan selama periode 2012--2019 mengalami pergeseran struktur dari sektor pertanian ke sektor industri.

Sebagai bentuk kontribusi ilmiah dari studi ini, penulis menyusun beberapa rekomendasi yang dinilai layak untuk menjadi pertimbangan. Pertama, prioritas pembangunan yang dapat dilakukan untuk mengurangi ketimpangan adalah meningkatkan aksesbilitas antar wilayah, khususnya di wilayah bagian barat Kalimantan yang mayoritas masih tertinggal. Salah satunya adalah dengan meningkatkan penyediaan infrastruktur transportasi, penyediaan moda transportasi perintis pada daerah-daerah yang tidak dapat dijangkau transportasi umum, dan pengembangan kerja sama antar daerah dalam pengembangan transportasi. Tindaklanjut dari saran ini terkait dengan instansi-instansi: Pemerintah Provinsi dan Pemerintah Kabupaten/Kota. Kedua, beberapa kebijakan yang dapat dilakukan Pemerintah Daerah khususnya pada bidang ekonomi adalah memperkuat struktur ekonomi di daerah-daerah tertinggal dan perbatasan dengan mengoptimalkan pengembangan komoditas unggulan, meningkatkan aktivitas industri pengolahan, dan daya tarik investasi. Pada bidang pendidikan, Pemerintah Daerah di daerah tertinggal harus lebih memprioritaskan pembangunan sarana dan prasarana pendidikan dasar dan menengah, sedangkan peningkatan kualitas pendidikan di daerah kaya harus mengikutsertakan peran perusahaan-perusahaan migas, batubara, dan 
industri besar. Tindak lanjut dari saran ini terkait dengan instansi-instansi: Pemerintah Provinsi dan Pemerintah Kabupaten/Kota.

Ketiga, program pembangunan di Kalimantan harus lebih diarahkan pada programprogram yang mendorong kinerja sektor pertanian. Pembangunan pertanian harus lebih diarahkan kepada upaya-upaya peningkatan produktivitas, mutu, nilai tambah produk (value added), dan daya saing produk (competitiveness). Tindakan penataan dasar yang dapat dilakukan Pemerintah Daerah adalah (1) pengembangan komoditas-komoditas yang memiliki peluang ekspor, investasi dan perdagangan; (2) mengembangkan kawasan ekonomi terpadu ataupun kawasan ekonomi khusus yang didasarkan pada keterkaitan antar sektor dan kawasan sentra produksi. Tindak lanjut dari saran ini terkait dengan instansi-instansi: Pemerintah Provinsi dan Pemerintah Kabupaten/Kota. Keempat, saat ini sektor pertambangan dan penggalian di Kalimantan mengalami kontraksi dan cenderung menurun sehingga dibutuhkan kebijakan yang lebih terarah agar mampu berdaya saing dengan daerah lain. Oleh karena itu, Pemerintah Daerah diharapkan lebih intensif melakukan koordinasi rencana investasi dengan swasta, lebih mengoptimalkan kerjasama antar daerah, dan lebih gencar melakukan upaya pemasaran potensi ekonomi unggulan untuk menarik para investor. Tindak lanjut dari saran ini terkait dengan instansi-instansi: Pemerintah Provinsi dan Pemerintah Kabupaten/Kota.

\section{REFERENSI}

Aiyar, S., \& Ebeke, C. (2020). Inequality of Opportunity, Inequality of Income and Economic Growth. World Development, 136, 1-10.

Akanbi, O. (2016). The Growth, Poverty and Inequality Nexus in South Africa: Cointegration and Causality Analysis. Development Southern Africa, 33(2), 1-20.

Alesina, A., \& Rodrik, D. (1994). Distributive Politics and Economic Growth. Quarterly Journal of Economics, 109(2), 465-490.

Andiny, P., Adelida, N., \& Meutia, R. (2019). Analisis Ketimpangan Pembangunan Antar Kabupaten/Kota (Studi Kasus Kabupaten Aceh Timur Dan Kota Langsa). 3(1), 47-56.

Andrei, A., \& Craciun, L. (2015). Inequality and Economic Growth: Theoretical and Operational Approach. Theoretical and Applied Economics, 22(1), 177-186.

Anggara, S., \& Sumantri, I. (2016). Administrasi Pembangunan: Teori dan Praktek (1st ed.). Penerbit Pustaka Setia Bandung.

Armstrong, Harvey., \& Taylor, Jim. (1993). Regional Economics and Policy. Second Edition. Great Britain: T.J Press (Padstow) Ltd.

Askar. (2019). Dimensi Keterlibatan Masyarakat dalam Program Pembangunan (Suatu Tinjauan Teoritis). Jurnal Sosio Sains, 5(1), 54-61. http://journal.lldikti9.id/sosiosains

Bargain, O., Dolls, M., Immervoll, H., Neumann, D., Peichl, A., Pestel, N., \& Siegloch, S. (2015). Tax Policy and Income Inequality in the United States, 1979-2007. Economic Inquiry, 53(2), 1061-1085.

Boediono. (1999). Teori Pertumbuhan Ekonomi. Yogyakarta: BPFE UGM.

BPS. (2016-2020). Produk Domestik Regional Bruto Provinsi-Provinsi di Indonesia Menurut Lapangan Usaha 2011-2015, 2012-2016, 2013-2017, 2014-2018, 2015-2019 Jakarta: BPS.

BPS. (2019). Gini Rasio 2002-2005 dan 2019-2020. Jakarta: BPS.

BPS Provinsi Kalimantan Timur. (2019). Analisis Isu Terkini Ketimpangan Wilayah Provinsi Kalimantan Timur 2018. Samarinda: BPS.

Bourguignon, F. (2018). World Changes in Inequality: An Overview of Facts, Causes, Consequences, and Policies. CESifo Economic Studies, 64(3), 345-370.

Chadha, N., \& Nandwani, B. (2018). Ethnic Fragmentation, Public Good Provision and Inequality in India, 1988-2012. Oxford Development Studies, 46(3), 363-377. 
Chaniago, A.A. (2011). Gagalnya Pembangunan: Kajian Ekonomi Politik Terhadap Akar Krisis Indonesia. Jakarta: Pustaka LP3ES.

Cheong, T. S., \& Wu, Y. (2014). The Impacts of Structural Transformation and Industrial Upgrading on Regional Inequality in China. China Economic Review, 31, 339-350.

Cita, F. P. (2016). Analisis Sumber- Sumber Pertumbuhan Ekonomi Dan Ketimpangan Wilayah Di Provinsi Nusa Tenggara Barat. Jurnal Ekonomi Dan Bisnis Indonesia, 1(2), 33-41.

Djojohadikusumo, S. (1994). Perkembangan Pemikiran Ekonomi: Dasar Teori Ekonomi Pertumbuhan dan Ekonomi Pembangunan. Jakarta: LP3ES.

Du Toit, C. C. (2015). Discerning Urban Spiritualities: Tahrir Square, Occupy Wall Street and The Idols of Global Market Capitalism. Verbum et Ecclesia, 36(1), 1-5.

Feenstra, R. C., \& Hanson, G. H. (2008). Global Production Sharing and Rising Inequality: A Survey of Trade and Wages. In E. K. Choi \& J. Harrigan (Eds.), Handbook of International Trade (Handbook o, pp. 147-185). Oxford: Blackwell Publishing Ltd.

Fisher, A. G. B. (1935). The Clash of Progress and Security. London: MacMillan \& Co. Ltd.

Furceri, D., Loungani, P., \& Zdzienicka, A. (2018). The Effects of Monetary Policy Shocks on Inequality. Journal of International Money and Finance, 85, 168-186.

Ghozali. (2014). Aplikasi analisis Multivariate dengan Program SPSS. Semarang: Badan Penerbit UNDIP.

Hasanah, U. (2017). Pengaruh Ketimpangan Pendapatan, Pendapatan Per Kapita, Dan Pengeluaran Pemerintah Di Bidang Kesehatan Terhadap Sektor Kesehatan Di Indonesia. Jurnal Ilmu Ekonomi Terapan, 2(1), 31-48.

Hesary, F. T., Yoshino, N., \& Shimizu, S. (2020). The Impact of Monetary and Tax Policy on Income Inequality in Japan. The World Economy, 43(10), 2600-2621. https://doi.org/10.1111/twec.12782

Ibrahim, H. R. (2017). Potret Pertumbuhan Ekonomi, Kesenjangan Dan Kemiskinan Di Indonesia Dalam Tinjauan Ekonomi Politik Pembangunan. Jurnal Ilmu Dan Budaya, 40(55), 6305-6328.

Iswanto, D. (2015). Ketimpangan Pendapatan Antar Kabupaten/Kota Dan Pertumbuhan Ekonomi Di Propinsi Jawa Timur. Signifikan: Jurnal Ilmu Ekonomi, 4(1), 41-66.

Jaumotte, F., \& Buitron, C. O. (2015). Inequality and Labor Market Institutions. Staff Discussion Notes, IMF Staff Discussion Note SDN/ 15/14, 1-31.

Karahan, F., \& Ozkan, S. (2013). On The Persistence of Income Shocks Over The Life Cycle: Evidence, Theory, and Implications. Review of Economic Dynamics, 16(3), 452-476.

Kementerian Energi Dan Sumber Daya Mineral Direktorat Jenderal Minyak Dan Gas Bumi. (2015). Rencana Strategis Direktorat Minyak Dan Gas Bumi Tahun 2015-2019.

Knox, A. D., \& Myrdal, G. (1960). Economic Theory and Under-Developed Regions. Economica, 27(107), 280-283. https://doi.org/10.2307/2601684

Knudsen, D. C., \& Barff, R. (1991). Shift-share analysis as a linear model. Environment \& Planning A, 23(3), 421-431. https://doi.org/10.1068/a230421

Kuznet, S. (1973). Modern Economic Growth: Indings and Reflections. The American Economic Review, 63(3), 247-258.

Kuznets, S. (1955). Economic Growth and Income Inequality. Economic Growth and Income Inequality, 45(1), 1-28.

Latuconsina, Z. M. Y. (2017). Analisis Faktor-faktor yang Mempengaruhi Indeks Pembangunan Manusia Kabupaten Malang Berbasis Pendekatan Perwilayahan dan Regresi Panel. Journal of Regional and Rural Development Planning, 1(2), 202-216. https://doi.org/10.29244/jp2wd.2017.1.2.202-216

Li, H., \& Zou, H. F. (1998). Income Inequality is Not Harmful For Growth: Theory and Evidence. Review of Development Economics, 2(3), 318-334. 
https://doi.org/10.1111/1467-9361.00045

Mardiana, I. W., Budhi, M. K. S., \& Swara, I. W. Y. (2017). Analisis Pergeseran Struktur Ekonomi dan Sektor Unggulan di Kabupaten Tabanan Provinsi Bali. E-Jurnal Ekonomi Pembangunan Universitas Udaya, 6(3), 414-444.

Maulana, A. (2019). Analisis Ketimpangan Pembangunan Antarkabupaten/Kota Di Provinsi Kalimantan Selatan Tahun 2010-2017. Jurnal Ilmu Ekonomi Pembangunan, 19(1), 1-6. Melikhova, O., \& Cizek, J. (2014). Kuznets Inverted U-curve Hypothesis Examined On UpTo Date Observations For 145 Countries. Prague Economic Papers, 23(3), 388-410.

Mubyarto. (1995). Pengantar Ekonomi Pertanian. Jakarta: PT. Pustaka LP3ES Indonesia.

Nangarumba, M. (2015). Analisis Pengaruh Struktur Ekonomi, Upah Minimum Provinsi, Belanja Modal, dan Investasi Terhadap Ketimpangan Pendapatan di Seluruh Provinsi di Indonesia Tahun 2005-2014. Jesp, 7(2), 9-26.

Nasaruddin, Zakaria, J., \& Sufri, M. (2020). Analisis Potensi Sektor Basis dan Pergeseran Struktur Ekonomi (Implikasinya Terhadap Perekonomian Kabupaten Maros). PARADOKS: Jurnal Ilmu Ekonomi, 3(1), 33-51.

Nasr, A. Ben, Balcilar, M., Akadiri, S. Saint, \& Gupta, R. (2018). Kuznets Curve for the US: A Reconsideration Using Cosummability. Social Indicators Research, 142(2), 827-843. https://doi.org/10.1007/s11205-018-1940-1

Omolara, C. (2019). Rostow's Growth Theory, Structural Transformation And Economic Development: The Nigerian Experience. International Journal of Arts \& Sciences, 12(1), 199-212.

Paul, S. G., \& Verdier, T. (1996). Inequality, Redistribution and Growth: A Challenge To The Conventional Political Economy Approach. European Economic Review, 40(3-5), 719728.

Persson, T., \& Tabellini, G. (1994). Is Inequality Harmful For Growth? American Economic Review, 84(3), 600-621. https://doi.org/10.2139/ssrn.1890847

Putri, A. D., \& Dartanto, T. (2016). Dekomposisi Perubahan Ketimpangan di Indonesia Tahun 2005-2014. Jurnal Ekonomi Dan Ekonomi Studi Pembangunan, 8(1), 72-91.

Raafi'i, A., Hakim, D. B., \& Putri, E. I. K. (2018). Ketimpangan Pembangunan Antarwilayah Pengembangan di Provinsi Papua Barat. Journal of Regional and Rural Development Planning, 2(3), 244-257.

Rahmadi, S., \& Parmadi, P. (2019). Pengaruh Ketimpangan Pendapatan dan Kemiskinan Terhadap Pertumbuhan Ekonomi Antar Pulau di Indonesia. Jurnal Paradigma Ekonomika, 14(2), 55-66.

Santosa, S. H. (2015). Disparitas Pertumbuhan Ekonomi Dan Pembangunan Ekonomi Wilayah Di Satuan Wilayah Pembangunan Iv Propinsi Jawa Timur. Media Trend, 10(2), 116-128.

Sarkawi, D., Oktaviani, A., Priadi, A., \& Khansa, T. (2018). Analisis Pelayanan Prima Atas Kepuasan Konsumen Pada Apotek K24 Bambu Apus Jakarta Timur. PETIR, 11(2), 125147.

Sjafrizal. (1997). Pertumbuhan Ekonomi dan Ketimpangan Regional Wilayah Indonesia Bagian Barat. Prisma, Nomor 3 Tahun XXVI, 34-52. Jakarta: Pustaka LP3ES Indonesia.

Sjafrizal. (2008). Ekonomi Wilayah dan Perkotaan. Jakarta: Raja Grafindo Persada.

Sukirno, S. (2012). Makroekonomi Teori Pengantar, Edisi Ketiga. Jakarta: Raja Grafindo Persada.

Theil, H. (1979). World Income Inequality and Its Components. Economics Letters, 2(1), 99102.

Tikson, D. T. (2005). Indikator-indikator Pembangunan Ekonomi. Semarang: Badan Penerbit Universitas Diponegoro.

Todaro, M., \& Smith, S.C. (2003). Economic Development, Edisi Kedelapan. United Kingdom: Pearson Education Limited. 
Todaro, M., \& Smith, S.C. (2006). Economic Development, Edisi Kesembilan, Jilid 1. (Drs. Haris Munandar, M.A.; Puji A.L., S.E, Trans). Jakarta: Penerbit Erlangga.

Weiss, J. (1998). Industry in Developing Countries: Theory, Policy and Evidence. London: Roudledge.

Williamson, J. G. (1965). Regional Inequality and the Process of National Development: A Description of the Patterns. Economic Development and Cultural Change, 13(4), 1-84. https://doi.org/10.1086/450136

Wiwekananda, I. B. P., \& Utama, I. M. S. (2016). Transformasi Struktur Ekonomi dan Sektor Unggulan di Kabupaten Buleleng Periode 2008-2013. Jurnal Ekonomi Kuantitatif Terapan, 9(1), 1-88.

Yasa, I. K. O. A., \& Arka, S. (2015). Pengaruh Pertumbuhan Ekonomi Dan Disparitas Pendapatan Antardaerah Terhadap Kesejahteraan Masyarakat Provinsi Bali. E-Jurnal Ekonomi Pembangunan Universitas Udaya, 8(1), 63-71.

Ye, X., Ma, L., Ye, K., Chen, J., \& Xie, Q. (2017). Analysis of Regional Inequality From Sectoral Structure, Spatial Policy and Economic Development: A Case Study of Chongqing, China. Sustainability (Switzerland), 9(4), 1-17. https://doi.org/10.3390/su9040633

Yusica, L. V., Malik, N., \& Arifin, Z. (2018). Analisis Pengaruh Pertumbuhan Ekonomi, Aglomerasi Dan Tingkat Pengangguran Terhadap Ketimpangan Antar Wilayah Kabupaten/Kota Di Provinsi Kalimantan Timur. Jurnal Ilmu Ekonomi, 2(2), 230-240. 
